\title{
UNDERSTANDING ORGANIZATIONAL ADAPTATION MECHANISMS IN MERGER AND ACQUISITIONS: A CASE STUDY FROM THE BANKING SECTOR
}

\section{DOI: 10.17261/Pressacademia.2021.1452}

RJBM- V.8-ISS.3-2021(5)-p.206-221

\section{Burak Pekcan ${ }^{1}$, Fatma Kusku²}

${ }^{1}$ Istanbul Technical University, Department of Management Engineering, Istanbul, Turkey. bpekcan@itu.edu.tr, ORCID: 0000-0002-4165-5033

${ }^{2}$ Istanbul Technical University, Department of Management Engineering, Istanbul, Turkey. kuskufa@itu.edu.tr, ORCID: 0000-0002-1436-4230

\begin{tabular}{l}
\hline Date Received: June 6, $2021 \quad$ Date Accepted: September 9, 2021 \\
\hline To cite this document \\
Pekcan, B., Kusku, F. (2021). Understanding organizational adaptation mechanisms in mergers and acquisition: a case study from the banking \\
sector. Research Journal of Business and Management (RJBM), 8(3), 206-221. \\
Permanent link to this document: http://doi.org/10.17261/Pressacademia.2021.1452 \\
Copyright: Published by PressAcademia and limited licensed re-use rights only.
\end{tabular}

\section{ABSTRACT}

Purpose- Merger and Acquisitions bring together organizational change. Adapting to this change is essential to be successful. Organizations need to harmonize their structures, processes and human resources in order to successfully adapt to this change. The current study aims to explore the post-integration mechanisms carried out after a multinational acquisition in Turkish context.

Methodology- This study is based on descriptive research design. Primary data were collected through interviews and observations made with the managers of the acquired organization. In addition, secondary data were collected by examining the notices and announcements, corporate presentations, changes in organizational structure over time and other internal resources of the acquired company.

Findings- Following the acquisition, various integration mechanisms are applied to align the structure, processes and human resources of both companies. In some aspects it was found in-depth integration and alignment, whereas some areas remain less changed or even unchanged. Also, it was observed that the application of mechanisms aimed for organizational alignment may differ from the already mentioned methods in the Post-Merger Integration literature.

Conclusion- Research results show that task integration mechanisms by themselves are not sufficient in the process of adaptation to postacquisition integration. Human and culture factors are at least as important as the first one on post-acquisition integration success. In the case examined, it is seen that various mechanisms were applied under both integration strategies within the acquired organization, and some additional mechanisms not mentioned directly in the literature.

Keywords: Merger and acquisition, organizational change, organizational adaptation, structural adaptation, cultural adaptation, Turkey JEL Codes: G34, M10, M14

\section{BIRLEŞME VE SATIN ALMALARDA ÖRGÜTSEL UYUM MEKANIZMALARINI ANLAMAK: BANKACILIK SEKTÖRÜNDEN BIR VAKA ARAŞTIRMASI}

\section{ÖZET}

Amaç- Birleşme ve satın almalar örgütsel değişimi de beraberinde getirmektedir. Başarılı olabilmek için, bu değişime uyum sağlanması çok önemlidir. Değişime uyum sağlanması için örgütlerin yapılarını, süreçlerini ve insan kaynaklarını da bu yönde uyumlu hale getirmeleri gerekmektedir. Bu araştırmada, Türkiye bağlamında gerçekleşen bir sınır ötesi satın alma işlemi sonrasındaki uyum mekanizmalarının açıklanması amaçlanmaktadır.

Yöntem- Bu çalışma açıklayııı araştırma tasarımına dayanmaktadır. Satın alınan kuruluş bünyesinde gerçekleștirilen araştırmada, birincil veriler (kuruluşun yöneticileri ile gerçekleştirilen mülakatlar ve gözlemler) ve ikincil veriler (satın alınan kuruluşun bildiri ve duyuruları, sunumları, organizasyon yapısında zaman içerisinde gerçekleşen değişimler ve diğer kuruluş içi kaynaklar) toplanarak değerlendirilmiştir.

Bulgular- Satın almanın ardından her iki şirketin yapısını, süreçlerini ve insan kaynaklarını uyumlu hale getirmek için çeşitli uyum mekanizmaları uygulanmışıı. Örgüt bünyesinde bazı alanlarda derinlemesine uyum gerçekleşirken, bazı alanlar daha az değişmiş veya değişmeden kalmıştır. Ayrıca, örgütsel uyumu hedefleyen mekanizmaların uygulanış biçiminin birleşme sonrası bütünleşme yazınında değinilen şeklinden farklılaşabileceği gözlemlenmiştir.

Sonuç- Araştırma sonuçları, satın alım sonrası değişime uyum sağlanması sürecinde yalnızca "görev bütünleşmesi" mekanizmalarının yeterli olmadığı, "insan" ve "kültür" faktörlerinin de satın alım sonrası bütünleșmenin başarısı üzerinde en az ilki kadar önemli olduğunu göstermektedir. Incelenen vakada, satın alınan kuruluş bünyesinde her iki bütünleşme stratejisi altında çeşitli uygulamaların birlikte gerçekleştirildiği, ayrıca yazında değinilmeyen bazı uygulamaların da her iki ana kavram altında pratikte uygulandığı görülmektedir.

Anahtar Kelimeler: Birleșme ve satın alma, örgütsel değişim, örgütsel uyum, yapısal uyum, kültürel uyum, Türkiye JEL Kodları: G34, M10, M14 


\section{GiRiş}

Çevresel belirsizliklerdeki artış ve küresel pazarlardaki rekabet prensiplerindeki değişimler nedeniyle firmalar rekabetçi kalabilmek için sürekli olarak büyüme potansiyelini ve pazardaki değişimleri gözden geçirmek durumundadır. İş ortamındaki bu zorluklara yanıt olarak, büyüme stratejisinin odak noktasını ve yönünü seçmek, şirketin rekabetçi konumunu belirleme konusunda yüksek derecede risk içeren kritik bir karar haline gelmiştir (Masiero ve diğ., 2017; Rexhepi ve diğ., 2017). Birleşme ve satın almalar, örgütlerin büyümeyi sağlamak, yeni pazarlara girmede rekabet avantajı kazanmak, ürün ve hizmet çeşitliliği sağlamak, riski azaltmak gibi çeşitli stratejik hedeflere ulaşabilmek için kullandıkları bir dışsal büyüme yoludur (Lechner ve Dowling, 2003, Cassia ve Minola, 2012, Pook ve diğ., 2017). Özellikle 1980 lerden itibaren, tüm dünyada finans sektörü başta olmak üzere çeşitli sektörlerde birleşme ve satın almalar gerçekleştirilmektedir. Oldukça popüler bir kurumsal büyüme stratejisi olmaya devam eden birleşme ve satın almalar, 2008 küresel finansal krizin ardından, küresel finansal sistemini oluşturan örgütler açısından daha da hız kazanmıştır. Böylelikle finansal hizmet kuruluşlarının sayısı önemli ölçüde azalırken, daha büyük, ürün ve hizmet çeşitliliği daha fazla ve daha geniş coğrafyalarda faaliyet gösteren örgütlerin yaşamını sürdürebildiği görülmektedir (DeYoung ve diğ., 2009).

Birleşme ve satın almalar, firmaların organik büyümeye kıyasla hızlı büyümelerine, yeni pazarlara girmelerine ve yeni müşterilere satış yapmalarına olanak tanır. Ayrıca, bir dizi tamamlayıcı ürün edinerek kapsamlarını genişletmelerini, AR-GE yoğun ürünlere, patentlere veya ticari sırlara sahip olmalarını, vergileri azaltmalarını, giderleri azaltarak maliyet avantajı yakalamalarını, rekabeti azaltmalarını ve sermayeye erişimi arttırmalarını sağlar (Renneboog ve Vansteenkiste, 2019). Sağladığı bu çok farkı faydalar nedeniyle, birleşme ve satın almalar finans, ekonomi, stratejik yönetim, örgütsel davranış ve süreç yaklaşımı gibi birçok yönetim disiplininin ilgisini çekmektedir. Bu alanda yapılan araştırmalar, çoğunlukla birleşme ve satın almaların nedenlerine (Elena ve Pascal, 2013; Bergman ve diğ., 2015, Lina ve Graziano, 2015; Nicholson ve Salaber, 2016), birleşme veya satın alma sonrasındaki finansal ve operasyonel performansın nasıl etkilendiğine (Ioannis ve Panayiotis, 2013; George ve diğ., 2016) ve verimliliğin nasıl değiştiğine (Radova, 2012; Rym ve diğ., 2013; Fadzlan ve Shah, 2014) odaklanmaktadır. Daha az sayıda akademik çalışma ise (örnek: Jemison ve Sitkin, 1986) birleşme ve satın alma ile birlikte kaçınılmaz olarak oluşan değişimle baş edebilmek için uygulanan çeşitli bütünleşme mekanizmalarına odaklanmıştır. Oysa, oluşan değişimle baş edebilme yolları olan bütünleşme mekanizmaları birleşme ve satın almaların beklenen başarıyı sağlaması ile doğrudan ilgilidir. Nitekim, birleşme ve satın alma işlemlerinin yüksek başarısızlık oranına sahip olduğu yazında dile getirilmekte ve birleşme ve satın alma sonrası bütünleşme ile ilgili sorunlar, başarısızlığın önemli nedenleri olarak sıklıkla vurgulanmaktadır (bkz. Khan ve diğ., 2020). Özellikle, küresel birleşme ve satın almalarda, sosyo-kültürel farklılıklar nedeniyle uyum sorunları daha çok ortaya çıkmaktadır (Birkinshaw ve diğ., 2000; Schuler ve Jackson, 2001; Aguilera ve Dencker, 2004; Teerikangas ve Very, 2006; Vaara ve diğ., 2007; Stahl \& Voigt, 2008; Stahl ve diğ., 2013). Sosyo-kültürel bütünleşme süreçlerinin kalitesinin birleşme ve satın almaların başarısı üzerinde önemli ölçüde etkili olduğu belirtilmektedir (Hajro, 2015). Dünyada, birleşme ve satın almalar, bir büyüme aracı olarak hızlı bir şekilde arttığına göre, bu işlemlerde başarı oranının artmasını sağlayacak olan bütünleşme mekanizmalarının daha yakından incelenmesi gerekmektedir. İşte, yazında bu konuda var olan eksiklik nedeniyle, bu çalışmada, sınır ötesi bir satın alma örneğine odaklanılmıştır. Araştırmada, satın alım sonrasında örgüt yapısı, işleyişi ve kültürünün satın alan örgütle nasıl uyum sağladığı, bu uyum sürecinde uygulanan uyum mekanizmalarının neler olduğu, nasıl uygulandığı ve sonucunda gerçekleşen örgütsel değişimin hangi boyutlarda daha yoğun gerçekleştiği açıklanmaktadır. Çalışmada, birleşme ve satın almalar açısından en aktif sektörlerden biri olan Bankacılık sektörüne (Hagendorf ve Keasey, 2009) odaklanılmakta ve Türkiye'de faaliyet gösteren ve yurt dışı merkezli bir örgüt tarafından satın alınan bir banka örneğinin bütünleşme süreci, yapı, süreçler ve insan kaynaklarındaki değişim boyutlarında ayrıntılı olarak incelenmektedir.

Birleşme ve satın alma alanındaki akademik araştırmaların çoğu, $A B D$ ve bir dizi $A B$ üyesi ülke gibi gelişmiş pazarlara odaklanmaktadır. Gelişmekte olan piyasalarda banka birleşme ve satın almaları, gelişmiş ekonomilere kıyasla daha yoğun olmasına karşın bu alandaki akademik araştırmalar sınırlıdır (Goddard ve diğ., 2012). Üstelik içinde bulunulan kurumsal çevrenin birleşme ve satın alma sonrasındaki stratejileri etkilediği yönünde de araştırma sonuçları bulunmaktadır (örnek, Hagendorff ve Keasey, 2009). Bu nedenle, özellikle 2000'li yıllardan itibaren yurtdışı merkezli büyük bankaların satın alma yolu ile pazara girdikleri Türkiye'de (Coşkun ve Karğın, 2016) bir satın alma sürecinin ve değişime uyum sağlama yollarının incelenmesi hem birleşme sonrası bütünleşmeye dair yazın hem de şirketlerdeki uygulamalar açısından anlamlı katkılar sunabilecektir. Ayrıca, bu araştırmada, satın alım sonrası bütünleşme yazınında kısıtlı değinilen veya değinilse de pratikte yazında belirtildiği şekilde uygulanmayan uyum mekanizmaları ortaya konulmaktadır. Böylelikle birleşme ve satın alma sürecinde oluşan değişimler ve bu değişimlere uyum sağlama biçimlerinin daha iyi anlaşılabilmesine çaba harcanmaktadır. Sınır ötesi birleşme ve satın alma örneklerinin incelendiği çok az sayıda çalışma bulunduğu için, bu çalışma ile bu alandaki yazında var olan birikime önemli derecede katkı sağlanmaktadır. 


\section{KAVRAMSAL ÇERÇEVE}

\subsection{Birleşme ve Satın Almalar: Bankacılık Sektöründe Yaşananlar ve Türkiye}

Örgütler var oldukları çevre içerisinde yaşamlarını sürdürebilmek için o çevre ile etkileşim halinde faaliyet göstermek zorundadır. Bu etkileşim süreci içinde, örgütler kimi zaman çevrede oluşan değişime uyum sağlama amacıyla (Kerber ve Buono, 2005), kimi zaman o çevreyi etkileme ve değiştirme isteğiyle (Pfeffer ve Salancik, 2003), kimi zaman da meşrulaşma amacıyla (DiMaggio ve Powell, 1983) değişim geçirmektedirler. Örgütsel büyüme de önemli bir çevreye uyum sağlama mekanizmasıdır. Büyüme, içsel (iç kaynakların kullanılması) veya dışsal (dış kaynaklardan yararlanılması) yöntemler ile sağlanabilmektedir (Ortiz-de-Urbina-Criado ve diğ., 2014). İçsel büyüme görece yavaş gerçekleşirken, dışsal büyüme teknolojiye, bilgi birikimine, finansal sermayeye ve pazar yeteneklerine erişimi kolaylaştırarak işletmelerin daha hızlı büyümelerini sağlamaktadır (Lechner ve Dowling, 2003, Isoraite, 2009; Cassia ve Minola, 2012, Pook ve diğ., 2017).

Dışsal büyüme kaynaklarının en önemlileri birleşme ve satın almalardır (Bauer ve Matzler, 2014). Birleşme ve satın almalar, değişmekte olan küresel piyasa ortamında çokuluslu şirketlerin ve ulusal büyük kuruluşların uyguladığı favori üst düzey büyüme stratejileridir. Satın almalar, şirketleri dönüştürmek ve kurumsal büyümeye ve yenilenmeye katkıda bulunmak anlamında eşsiz bir potansiyele sahiptir (Haspeslagh ve Jemison, 1991). 1990 sonrası; bilgi ve iletişim teknolojilerinde yaşanan hızlı gelişmelerin, yasal engellerin azaltılmasının, etkinliği, verimliliği ve büyümeyi teşvik eden küreselleşme eğiliminin etkisiyle birleşme ve satın alma işlemlerinde hızlı artış gerçekleşmiştir. Daha fazla verimlilik ve etkinlik beklentisi ile birleşme ve satın almalar sınır ötesi ülkelere taşınmıştır. Sınır ötesi birleşmeler, farklı ülkelerde bulunan uygun maliyetli kaynaklara (işgücü, hammadde, teknoloji vb.) ulaşımı kolaylaştırırken, pazar payını daha fazla arttırma imkânını da sunmuştur. Son yirmi yılda gerçekleşen bu büyük değişim furyasından, finans sisteminin merkezi olan bankacılık sektörü de etkilenmiştir. Sektörde, sınır ötesi banka birleşmeleri yaygınlaşmıştır (Coşkun ve Karğın, 2016).

Büyümeyi sağlama açısından birleşme ve satın alma stratejisinin popülaritesine rağmen araştırmalarda, gerçekleşen uygulamaların pek çoğunda hisse değeri, yatırımın geri dönüşü ve birleşme sonrası karlılık anlamında beklenen amaca ulaşılamadığı belirtilmektedir (örnek, Carleton, 1997; Wright ve diğ., 2001; Khan ve diğ., 2020). Birleşme ve satın almaların ancak \%25-35'inin istenen hedeflere ulaştığı ve başarılı olarak kabul edilebileceği görülmüştür (Marks ve Mirvis, 2001; Schweiger, 2002; Ellis ve Lamont, 2004; Pablo ve Javidan, 2009). Önemli sayıda araştırma banka birleşmelerinin performansa etkilerini araştırmış ve varlıkların getirisi (Houston ve diğ., 2001, DeLong, 2003, Zollo ve Singh, 2004), özkaynak karlılığı (Akhavein ve diğ., 1997; Altunbaş ve Ibanez, 2004) veya faaliyet karlılığı (Lindner ve Crane, 1993) gibi performans göstergelerinin gelişimi üzerinde birleşme ve satın almanın önemli bir etkisine rastlanmamıştır.

Lindblom ve Von (2002), Amerika bankacılık sektöründe çoğunlukla ülke içindeki kuruluşların birleştiğini, Avrupa'da ise çoğunlukla sınır ötesi birleşme ve satın almaların gerçekleştiğini belirtmiştir. Aynı ülke içindeki birleşme ve satın alma örneklerinin pek çoğunda istenen sonuçlara ulaşılamadığı, oysa coğrafi farklılaşmanın daha iyi sonuçlara yol açtığı yönünde araştırma sonuçları bulunmaktadır. Örneğin Bernad ve diğ. (2010), İspanya bankacılık sektöründe birleşme ve satın almaların yalnızca yarısında işletmelerin uzun dönem üretkenliklerini arttırdıklarını belirtmiştir. Oysa Goddard ve diğ. (2012), Asya ve Latin Amerika Bankacılık sektöründe gerçekleştirdikleri çalışmalarında, coğrafi farklılaşmanın satın alanlar için değer yarattı̆̆ı sonucuna ulaşmışlardır. Benzer şekilde, Jianbo ve Liu (2013), sınır ötesi birleşme ve satın almaların altında yatan sebepleri, alınan aksiyonları ve birleşmenin etkinliğini araştırmış, vaka olarak inceledikleri bankanın gerçekleştirdiği sınır ötesi satın almalarla önemli başarılar elde ettiğini belirtmişlerdir.

Bankacılık sektöründe gerçekleştirilen birleşme ve satın alma örnekleri yazında değişik açılardan değerlendirilmiştir. Araştırmalarda sıklıkla birleşme ve satın almaların altında yatan nedenler ile başarıyı sağlayan unsurlar üzerine odaklanılmıştır (örnek, Lina ve Graziano, 2015; Johan, 2018). Örneğin, Avrupa bankacılık sektöründe bir inceleme yapan Elena ve Pascal (2013) satın alan ve satın alınan kuruluşların hangi özellikleri taşıdığını araştırmıştır. Lindblom ve Von (2002) ise, Kuzey Avrupa'da gerçekleşen Nordbanken ve Merita birleşmesini inceledikleri araştırmalarında, stratejik uyumun birleşmenin başarısı üzerinde tamamlayııı etkisi olduğunu belirtmiş, birleşen bankaların farklı özelliklerini ve güçlü yönlerini çapraz kullanabilmelerinin birleşmenin başarısı üzerinde önemli etkileri olduğunu belirtmiştir. İlgili yazında, örgütsel büyüklüğün birleşme ve satın almaların performansına etkileri de araştırılmıştır. Örneğin George ve diğ. (2016) Japonya bankacılık sektöründe 2000-2008 yılları arasında 97 adet bankayı inceledikleri araştırmalarında, küçük ölçekli bankaların gerçekleştirdikleri birleşme ve satın almaların daha büyük ölçekli bankalara kıyasla daha verimli olduğu sonucuna ulaşmışlardır.

Dünyada olduğu gibi Türkiye Bankacılık sektöründe de, birleşme ve satın almalar, son yıllarda sıklıkla görülen örgütsel büyüme stratejileri arasındadır. Türkiye bankacılık sektörü Kasım 2000 ve Şubat 2001 krizlerinden önemli ölçüde etkilenmiştir. Bu iki krizin derin etkileri nedeniyle 2001 yılında “Bankacılık Sektörü Yeniden Yapılandırma Programı” uygulanmaya konularak sektörün sorunları giderilmeye, aynı zamanda olası krizler karşısında sağlamlığı arttırılmaya çalışılmıştır. Bu süreçte Bankacılık Düzenleme ve Denetleme Kurumu 13 adet bankayı birleştirmiş, 5 tanesini faaliyet gösteren diğer bankalara satmış, 3 bankayı tasfiye etmiş ve 1 bankayı ise Tasarruf Mevduatı Sigorta Fonu (TMSF) bünyesinde varlık yönetimi geçiş bankası olarak 
yapılandırmıştır (Sarıgül ve Kurşunel, 2012). Yapılandırma programı sınır ötesi satın almaların da yolunu açmış ve yabancı sermayeli bankalar Türkiye'de bankacılık sektörüne yatırımlar yapmaya başlamışlardır. Bu dönemde, bankalar kanununun esnekleştirilmesinin ardından birleşmeler ve satın almalar teşvik edilmiştir (Yıldırım; 2005). Bu süreçte bazı yabancı yatırımcılar, Türk bankalarını satın almaya, onlarla ortaklık kurmaya ve bazı yabancı bankalar da Türk bankaları ile birleşmeye niyetlenmişlerdir (Abbasoğlu ve diğ., 2007).

\subsection{Birleşme ve Satın Almalarda Örgütsel Değişim ve Uyum Mekanizmaları}

Örgütler çevreleriyle etkileşim içinde bulunmakla birlikte, onu değiştirme gücüne sahip değildir. Bu nedenle çevrede oluşan değişime uyum sağlama sürecinde örgütün bünyesinde çeşitli revizyonlara gidilmekte, yani örgütte belirli değişimler oluşmaktadır. Örgüt birleşme ve satın almaları da, bir anlamda çevredeki değişimle mücadele edebilme yolu olarak ortaya çıktığından, kaçınılmaz olarak, bu işlemi gerçekleştiren örgütlerde bazı değişimlere yol açmaktadır. Bu değişimin odağında, teknoloji, strateji, yapı, sistem, kültür, çalışanlar ve paylaşılan değerler gibi unsurlar bulunmaktadır (Hitt ve diğ., 2009).

Yazında, tüm değer yaratımının satın alımdan/birleşmeden sonraki süreçte gerçekleştiği belirtilmekte (Haspeslagh ve Jemison, 1991) ve değer yaratılmasını sağlayan unsurların neler olduğu sorusu sorulmaktadır. Birleşme sonrası ve satın alım sonrası bütünleşmeyi kapsayan araştırmalar, 1980'lerin sonuna doğru güç kazanmış ve sonrasında da kendisine geniş bir araştırma alanı bulmuştur (Teerikangas ve diğ., 2012). Schweiger ve Goulet (2005), birleşme ve satın almalarda bütünleşme üzerine tutarlı bir anlayış geliştirme çağrısında bulunmuştur. Bu çağrıyı takiben, birleşme ve satın almalarda bütünleşmenin farklı yönleri üzerine birçok araştırma gerçekleştirilmiş, ancak örgütsel değişim sürecindeki bütünleşme mekanizmaları ve bunların uygulanış biçimleri üzerine gerçekleştirilen çalışmalar nispeten sınırlı kalış̧tır. Birleşme ve satın almalar üzerine genel araştırmalar (Tuch ve O'Sullivan, 2007; Stahl ve diğ., 2013) yapıldığı gibi, kültür (Schoenberg 2000; Stahl ve Voigt, 2008), sosyal kimlik (Ullrich ve van Dick, 2007), liderlik (Sarala ve diğ., 2014), uluslararası satın almalar (Ghauri ve Buckley, 2003) veya yöntem (Meglio ve Risberg 2011; Cartwright ve diğ., 2012) gibi spesifik alt başlıklarda da araştırmalar yayımlanmıştır. Haspeslagh ve Jemison'un (1991) birleşme veya satın almadan sonra değer yaratılmasını sağlayan unsurların neler olduğu sorusuna, diğer araştırmacılar (örnek: Birkinshaw ve diğ., 2000; Gomes ve diğ., 2012; Bansal, 2015), "insan kaynakları bütünleşmesi" ve "görev bütünleşmesi" mekanizmaları tanımlayarak yanıt vermişlerdir.

Görev bütünleşmesi, birleşmiş şirketin faaliyetlerinin daha etkin bir şekilde işlemesini kolaylaştırmak ve maksimum operasyonel sinerjiyi elde etmek için bazı faaliyetlerin yeniden tasarlanması, yani örgütsel yapı ve süreçler üzerinde durmaktadır (Sales ve Mirvis, 1984; Shrivastava, 1986; Haspeslagh ve Jemison, 1991). Birleşme ve satın alma alanında farklı araştırmacılar tarafından önemli olduğu belirtilen görev bütünleşmesi mekanizmalarına örnek olarak, ortak toplantılar, ortak proje ekipleri, bilgi paylaşımı, beceri transferi ve personel rotasyonu faaliyetleri gibi unsurlar belirtilmektedir (Bansal, 2015). Belirtilen görev bütünleşmesi mekanizmaları ile örgütlerin yapı ve süreçleri arasında uyum sağlanması amaçlanmaktadır.

Birleşme ve satın alma sürecini inceleyen araştırmalarda sıkça konu edilen (Örnek, Lin ve diğ., 2006; Gomes ve diğ., 2012) insan kaynakları bütünleşmesi ise, her iki taraftaki çalışanlar arasında ortak değerler oluşturulması ve bütünleşmeye yönelik olumlu tutumların yaratılması olarak tanımlanmaktadır (Birkinshaw ve diğ., 2000, s.400). Bu süreçte, farklı örgüt kültürlerinin bir potada eritilerek birleştirilmesi ve farklı kültürlerin harmanlanması amaçlanmaktadır (Bijlsma-Frankema, 2001). Sosyokültürel veya sosyal bütünleşme olarak da bilinen insan kaynakları bütünleşme süreci birleşme ve satın almalarda çalışanlar arasında ortak bir kimlik ve değerler oluşturularak tatmin yaratılmasına odaklanır (Dauber, 2009). Ortak değerler, normlar ve davranışlar, birleşen örgütlerde güvenin gelişimini desteklemekte ve ilişkilerdeki çatışma potansiyelini azaltmaktadır (Vaara ve diğ., 2007). Lin ve diğ. (2006), Amerika bankacılık sektöründe gerçekleştirdikleri araştırmada, birleşme ve satın almaların özellikle insan kaynaklarını etkin yöneten kuruluşlar için avantaj yarattığı sonucuna ulaşmıştır.

Birleşme ve satın alma süreçlerinin beklenen amaçlara ulaştıracak bir şekilde gerçekleşebilmesi için, araştırmacılar, iletişimin artırılması (Schweiger ve Denisi, 1991), sosyokültürel eğitim (Vaara ve diğ., 2003), kendi ülkesinin dışında çalışan kişilerden (expatlardan) faydalanılması (Hebert ve diğ., 2005), kimlik oluşturma kampanyaları (Vaara ve diğ., 2007), kültürel bilinçlendirme seminerleri gibi ortak örgütsel faaliyetler, rekreasyon programları gibi çalışma saatlerinden sonra yapılan ortak gayri resmi faaliyetler ve işyerinde gayrı resmi etkileşim olanakları (Bansal, 2015) gibi insan kaynakları bütünleşme mekanizmaları önermişlerdir. Aslında, bir anlamda, belirtilen öneriler ile fiziksel birleşme yanında ruhsal birleşmenin sağlanması yani kültürel uyumun gerçekleşmesi kolaylaştırılmaya çalışılmaktadır. Özellikle küresel birleşme ve satın almalar, kültürel ve kurumsal farklılıklar nedeniyle inançlar, değerler ve uygulamalar açısından uyumsuzluk yaratmakta, bu da kaygı ve düşmanlık duygularına yol açmakta (Khan ve diğ., 2020), dolayısı ile birleşme/satın almanın başarılı olma oranı düşmektedir. Bu nedenle, kültürel uyumun sağlanması, birleşme ve/veya satın alma işlevinin başarısı açısından çok önemli hale gelmektedir.

Ancak, birleşme ve satın alma sürecinin yol açtığı örgütsel değişim, örgüt yapısı, çalışanlar, iş süreçleri, izleme ve kontrol mekanizmalarının tamamını etkileyen ve bunların tamamından etkilenen bütünsel bir süreçtir. Bu nedenle, bazı araştırmacıların da (örnek, Gadiesh ve Ormiston, 2002; Thakur ve Bansal, 2015) belirttiği gibi, sadece tek bir bütünleşme mekanizmasına odaklanmak yerine, başarılı olabilmek için işletmelerin birleşme ve satın alma sonrası bütünleşme sürecine katkıda bulunan nedenlerin tümüne birden, eş zamanlı olarak bakılması anlamlı olacaktır. Bundan dolayı, bu çalışmada, 
birleşme ve satın alma sürecinin başarısı üzerinde önemli etkileri olan hem görev hem de insan kaynakları odaklı bütünleşme beraberce incelenmektedir.

Çalışmanın ilerleyen bölümünde, küresel düzeyde gerçekleştirilen bir satın alma vakası incelenerek, satın alma sonucunda oluşan örgütsel değişim sürecinde, örgütsel uyumun sağlanması yönünde yapısal, fonksiyonel (süreç) ve kültürel (insan kaynakları alanlarında) uyumun sağlanması için hangi mekanizmaların uygulandığı, yazında değinilen mekanizmaların yanında farklı mekanizmaların da uygulanıp uygulanmadığı sorularının yanıtları aranmaktadır.

\section{YÖNTEM}

Araştırmada, Türkiye Bankacılık sektöründeki bir örgütün, yine bankacılık sektöründe çok sayıda ülkede faaliyet göstermekte olan, kendi örgütsel büyümesini de çoğunlukla birleşme ve satın almalar ile gerçekleştirmiş bir grup tarafından satın alınması sonrasında yaşadıklarına odaklanılmaktadır. Satın alım sonrasında, örgütsel uyumun yapı, işleyiş ve kültürel boyutlarda sağlanması için gerçekleştirilen çalışmalar açıklayıcı vaka araştırması yöntemi ile incelenmektedir.

Vaka araştırması yöntemi, zaman içerisinde tıp bilimleri, sosyoloji, siyaset, hukuk, yönetim ve mühendislik gibi farklı disiplinlerde önemi gittikçe artan, en önemli ve erişilebilir nitel araştırma metotlarından birisidir (Reddy, 2015). Vaka araştırmasında, araştırmacı "neden" ve "nasıl”" sorularına cevap aradığı (Eisenhardt, 1989, Eisenhardt ve Graebner,2007), ancak olaylar üzerinde kontrolü bulunmadığı zaman veya araştırabileceği olayı gerçek zamanlı araştırma imkânı bulunuyorsa başvurulacak bir yöntemdir. Yin'e (2003, s.13) göre, vaka araştırması yöntemi, özellikle olay ve içerik arasındaki bağ birbirinden tam olarak ayrışmıyorken kullanılan bir araştırma stratejisidir. Güncel bir olguyu gerçek hayat bağlamında araştıran deneysel bir araştırmadır. Bir vaka araştırması sorusu birden fazla kanıt arar, verinin doğrulanmak için üçgenlemeye ihtiyaç duyduğunu göz önüne alır. Daha önce yapılmış teorik önerilerden veri toplanması için ve analiz için yararlanır. Diğer bir deyişle, bir program, bir olay, bir kişi, bir süreç, bir kurum veya bir sosyal grup gibi belirli bir olgunun incelenmesidir (Willis, 2007). Bunun da ötesinde, nitel araştırma yöntemleri, daha sınırlı bir olguyu açıklamaya çalışırken farklı bilgileri kullanan, idiografik araştırma yaklaşımlarının meşru bir aracıdır (Yin, 2003).

Araştırmanın veri toplama sürecinde nitel araştırma tasarımı uygulanarak tümdengelim ve tümevarım yaklaşımları bir arada kullanılmıştır. Çalışmanın başlangıcında, Haspeslagh ve Jemison (1991) ve Birkinshaw ve diğ.'nin (2000) önerdiği, kavramsal çerçevenin araştırılması için önce tümdengelim yaklaşımı ile literatür bulgularına bakılarak araştırılacak değişkenler belirlenmiştir (Angwin ve Meadows, 2015). Ardından, incelenen konu doğrultusunda, belirlenen değişkenler dikkate alınarak veri toplanmıştır. Sonra, elde edilen veriler tümevarım yaklaşımı (Bryman, 2008) ile analiz edilmiştir. Tümevarım yaklaşımı, çevrenin ayrıntılı olarak gözlemlenmesi ve sonrasında daha özet genellemeler ve fikirlere ulaşılmasını kolaylaştırdığı, ayrıca araştırmacıları hiçbir kuramsal / kavramsal yaklaşımın etkisi altında kalmadan, özgürce analiz yapmaya ve değerlendirmeye yönlendirdiği için (Bernard, 2011; Neuman, 2003) tercih edilmiştir.

Bu araştırma için veriler birincil (görüşmeler ve gözlemler) ve ikincil (basılı doküman incelemeleri) veri kaynaklarından yararlanılarak toplanmıştır. Görüşmelerin kimlerle gerçekleştirileceğinin belirlenmesinde, araştırılan konu hakkında ilgili ve bilgili kişilerin deneyimlerine ve bilgilerine başvurulması yöntemiyle (Johnson ve diğ., 2007) ilerleyen amaçlı örnekleme kullanılmıştır. Amaçlı örnekleme kullanılarak satın alım sonrası uyum süreci (Creswell, 2012) hakkında zengin açıklamalar geliştirilebilmesi için bu süreci yaşamış ve mevcut durumda da örgüt bünyesinde çalışmakta olan müdür ve yönetici görevlerindeki toplam 18 katılımcı ile farklı tarihlerde 45 dakika ile 1,5 saat arasında süren görüşmeler gerçekleştirilmiştir. Nitel araştırmanın temel örneklem yöntemi olan "amaçlı örneklem", olasılıksız-seçkili örneklemedir. Bu yöntemde temsil edilebilirlik değil, örneklemin araştırma konusu ile ilişkisi daha önemlidir; bu kapsamda zengin ve derin bilgiye ulaşılır ve amaçlanan konuda geneli temsil kabiliyeti artırılmaya çalışılır (Flick, 2009). Görüşme gerçekleştirilen kişilerin, satın alım sonrasında örgütte değişimin yaşandığı temel birimlerin yöneticileri olması, görüşme gerçekleştirildiği sırada halen örgüt nezdinde çalışıyor olmaları, değişim sürecinde örgütte gerçekleştirilen yapısal ve kültürel uyumun sağlanmasında değişimin merkezinde rol almaları nedeniyle, bu kişiler ile gerçekleştirilen görüşmeler örgütteki değişim sürecinin anlaşılabilmesinde yeterlidir. Kendilerine ulaşılamaması nedeniyle görüşme yapılamayan az sayıda yönetici bulunsa da, örgütten toplanan ikincil veriler bu alanlardaki değişimin açıklanmasında yeterlidir. Görüşme soruları, satın alım sonrasındaki değişim sürecini açıklamaya yönelik hazırlanmış, örgüt yapısında, iş süreçlerinde, görüşülen kişilerin kendi sorumluluk alanlarında ve iş yapış biçimlerinde gerçekleşen değişimlerin ortaya çıkarılabilmesi için açık uçlu olarak düzenlenmiştir (Jemison ve Sitkin, 1986; Haspeslagh ve Jemison, 1991; Birkinshaw ve diğ., 2000; Steele, 2014).

Yazın taraması sonuçlarından (örnek, Haspeslagh ve Jemison, 1991; Schweiger, 2002; Weber ve Tarba, 2010) hareketle, görüşmelerde katılımcılara, satın alım sonrasında örgütün yapısında, işlevlerinde ve insan kaynakları yönetimi alanında ne tür değişimlerin olduğu ve söz konusu değişimlerin yoğunluğu hakkında sorular sorulmuştur. Görüşmelerden elde edilen veriler görüşme sırasında kısaca, sonrasında ayrıntılı olarak yazılmış, yazılanlar tekrarlı biçimde okunmuş, bu sayede satın alım sonrasında örgütte gerçekleşen temel değişimlerin ve bu değişimlerin sağlanmasına yönelik uygulanan uyum mekanizmalarının neler olduğu ortaya çıkarılmıştır. 
Araştırmada ikincil veriler, satın alım sonrasında örgüt içinde yayımlanan bildiri ve duyuruların taranması, örgüt içerisinde gönderilen e-postaların okunması, basılı süreç dokümanlarının (iş planları, birimlerle ilgili yönetmelikler, süreçlerle ilgili rehberler, kurallar vb.) ve çeşitli sunumların incelenmesi ile toplanmıştır. İkincil verilerden elde edilen bilgiler, birincil verilerden elde edilen bilgiler ile birleştirilerek araştırma bulgularına ulaşılmıştır. Tümevarım yaklaşımı nitel verilerin incelenebilmesine, gruplanmasına, elde edilen bilgilerin değişim sürecini açıklayan alt temalara dönüştürülebilmesine ve işlenebilmesine olanak sağlamıştır.

\section{BULGULAR VE TARTIŞMA}

Satın alım sonrasında, satın alınan örgütün satın alan örgüte yapısal, işlevsel (fonksiyonel) ve kültürel (iK) bakımdan uyum sağlamasına yönelik bir uyum süreci başlatılmıştır.

\subsection{Satın Alan Örgüte Yapısal Uyum}

Satın alım sonrasında satın alınan örgütün organizasyon yapısında önemli ölçüde değişim gerçekleşmiştir. Örgütün, satın alım öncesindeki organizasyon yapısı satın alım sonrasındaki yapı ile karşılaştıııldığında, bazı birimlerin yeni kurulduğu, bazılarının ise sorumluluklarının veya bağlılıklarının değiştirildiği görülmektedir. Temel değişimler şu şekilde özetlenebilir:

Kredi riski yönetimi birimlerinin tek çatı altında toplanması: Satın alım sonrasında, satın alınan örgütün kredi değerlendirme, kredi tahsisi, kredilerin takibi ve tahsilat süreçlerinin tamamı tek bir çatı altında toplanmıştır. Bununla birlikte, grup genelindeki raporlamalara ve uluslararası finansal raporlama standartlarına uyum sağlanabilmesi için yine bu yapı altında risk planlama, izleme ve raporlama departmanı kurulmuştur. Ticari krediler ve kurumsal krediler birimleri ayrılarak grup genelindeki yapıya uyumlu hale getirilmiştir. Ayrıca, otomasyon sistemi tarafından değerlendirilen krediler için yine grup genelindeki yapıya uygun olarak bireysel krediler risk stratejileri departmanı kurulmuştur.

Hazine yönetimi yapılanmasının ayrıştırılması: Satın alım sonrasında, hazine yönetimi yapılanmasında değişikliğe gidilerek, Bankanın kendi namına gerçekleştirdiği hazine işlemleri ile müşteriler adına gerçekleştirilen hazine işlemlerinin yönetimi ayrı birimlerin sorumluluğuna verilmiştir.

Risk yönetimi yapılanmasının ayrıştırılması: Risk yönetimi tarafındaki en temel yapısal değişiklik, piyasa riski ve yapısal risk yönetimi ile sermaye ve operasyonel risk yönetiminin ayrıştırılarak farklı iki birim sorumluluğuna verilmesidir. Bu iki birim de Risk Yönetimi Başkanlığına, o da Yönetim Kurulu'na bağlı Risk Komitesine raporlayacak şekilde yeniden konumlandırılmıştır.

Komiteler yapılanmasındaki değişim: Organizasyon yapısı değişirken, örgütün komiteler yapılanması da değişmiştir. Satın alım öncesinde örgütte çok sayıda komite bulunurken, satın alım sonrasında bu komitelerden bazıları kapatılmış, satın alan grubun komite yapılanmasına paralel yeni komiteler kurulmuş, bazı komiteler ise kapsamındaki faaliyetlerin niteliği sebebiyle birleştirilmiştir. Yeni komiteler ve bu komitelerin görev ve sorumlulukları banka intranetinde değişiklikler yapıldıkça yeniden yayımlanmıştır.

Iç kontrol ve iç denetim yapısındaki değişim: Satın alım sonrasında örgütün iç kontrol fonksiyonunun yapısı, satın alan gruba uyumlu şekilde birinci ve ikinci seviye kontroller ayrıştırılarak yeniden düzenlenirken, iç denetim fonksiyonunun organizasyon yapısı da lokasyon temelli denetim yapılanmasından risk ve süreç temelli yapıya doğru değişim geçirmiştir.

Yapısal uyumun sağlanması yönünde gerçekleştirilen değişikliklere ilişkin satın alınan örgütün tüm çalışanlarına farklı zamanlarda yeni organizasyon yapısı ve görev değişiklikleri hakkında şirket intranetinden yayımlanan duyurular ile veya genel müdür tarafından e-postalar ile bilgilendirmeler yapıımıştır.

\subsection{Satın Alan Örgüte Fonksiyonel Uyum}

Satın alım sonrasında, satın alan örgüte fonksiyonel uyumun sağlanabilmesi için, satın alınan örgütün pek çok fonksiyonunda kapsamlı değişimler olmuştur:

Risk yönetiminde çeşitli risk izleme metriklerinin uygulanmaya başlanması: Satın alım sonrasındaki uyum sürecinde, satın alınan örgütün risk iştahını düzenleyici çok sayıda limitler ve metrikler getirilmiştir. Özellikle likidite, faiz ve yabancı para riskleri üzerine getirilen bu metrikler, bankanın kendi adına ve müşteriler adına gerçekleştireceği işlemlerin ayrıştırılması, farklı ürün ve müşteri grupları için de çeşitli limitler getirilmesi, satın alınan örgütün satın alan örgüte risk iştahı açısından yakınsamasını sağlamıştır.

Krediler sürecinin yeniden yapılandırılması: Fonksiyonel anlamda uyum sağlanması yolunda gerçekleşen en büyük değişimlerden birisi de kredi riski yönetim süreçlerinin yeniden kurgulanmasıdır. Satın alan kuruluşun kredi delegasyon kuralları satın alınan kuruluşta da uygulanmaya başlanmış, spesifik alanlar ve özellikli krediler için yetki dağılımı satın alan gruba uyumlu hale getirilmiştir. Diğer yandan, kredi yapılandırma ve yeniden finansman (refinansman) işlemlerinde de söz konusu kurallar satın alınan kuruluşta uygulanmaya başlanmıştır. Satın alınan banka ve iştiraklerinde kredi tahsis sürecini önemli ölçüde etkileyen konsolide limit yönetim süreci uygulanmaya başlanmıştır. Yine krediler alanında, ticari müşterilerin 
mali durumları ve faaliyetlerinde oluşabilecek sorunların önceden tespit edilmesi ve olası risklerin etkin takibi amacıyla geliştirilen "Erken Uyarı Sistemi" uygulamaya alınmıştır.

Komitelerin kuruluş ve işleyiş sürecinin benzeştirilmesi: Satın alınan örgütte, satın alan grubun uygulamalarına paralel olarak, komitelerin kuruluş ve işleyiş sürecinde de bazı değişimler gerçekleşmiştir. Komite kuruluş ve işleyiş prosedürü oluşturulmuş, komitelerde alınan kararlar yazııı hale getirilerek katılımcılar ile paylaşılıp, satın alım öncesine kıyasla, tutanaklar ile daha ayrıntılı bir şekilde kayıt altına alınmaya başlanmıştır.

Karar verme sürecinde merkeziyetçiliğin artması: Satın alımı takiben bankanın iştiraklerinin yönetiminde daha merkeziyetçi bir anlayışı hâkim kılan bir değişim süreci yaşanmıştır. Satın alım sonrasında, satın alınan örgütün iştiraklerinin mali ve operasyonel süreçlerini etkileyen büyük kararlar merkezden alınmaya başlanmıştır. Bu kapsamda iştirakleri de kapsayan politika ve prosedürler oluşturulmuştur. Satın alınan bankaya uygulanan varlık yönetim limitleri, risk metrikleri ve risk iştahı, ayrıca izleme ve raporlama yükümlülüklerine bankanın iştirakleri de tabi tutulmuştur.

Finansal raporlama sisteminin satın alan kuruluşa uyumlu hale getirilmesi: Satın alım sonrasında, satın alınan kuruluşun finansal raporlama ve muhasebe sistemi satın alan kuruluşa uyumlu hale getirilmiştir. Verilerin nerede ve nasıl tutulacağı, verilerin raporlanmasında uyulması gereken formatlar ve rapor düzenleme kriterleri, muhasebe ve raporlama dilinin uyumlaştırılması, satın alım sonrasında odaklanılan temel alanlardır. Bu değişimler sürerken, satın alınan kuruluşun kendi iç raporlamalarında da benzer değişimlerin olduğu gözlenmiştir. Üst yönetime yapılmakta olan sunumların içerikleri ve formatı, satın alan kuruluşa yapılmakta olan formatlara benzer hale gelmiştir.

Bütçe ve raporlama sürecindeki değişim: Satın alınan örgütün tüm hizmet alımlarına ilişkin süreçlere dair yönetim modelinin ve prosedürlerin saptanması, harcamaların stratejik, finansal ve teknik kriterlerle değerlendirilerek verimlilik esasına göre önceliklendirilmesi amaçlanmıştır. Bu kapsamda bütçe ve raporlama sürecinde değişikliğe gidilmiş, proje harcamaları ve rutin dışı giderlere ilişkin tutar bazında yetkileri gösteren süreç yönetmeliği yayımlanmıştır.

Sektör ile ilgili çeşitli Avrupa düzenlemelerine uyum sağlanması: Satın alım sonrasında, satın alınan örgütün Avrupa Bankacılık sektörü düzenleyici otoritelerinin (örnek, European Banking Authority, European Central Bank) bazı düzenlemelerine de uyum sağlaması gerekliliği doğmuştur. Bu durum, beraberinde bu otoriteler için de ana gruba raporlama yapma ihtiyacını doğurmuştur. Raporlama süreçleri bu kapsamda da bir değişim geçirmiştir.

Satın alma faaliyetlerinin merkezileştirilmesi: Satın alım öncesinde örgütün satın alma faaliyetleri ihtiyaç sahibi olan birimler tarafından yürütülmekte iken, satım alım sonrasında söz konusu faaliyetlerin grup uygulamalarına uyumlu olacak biçimde merkezi bir şekilde yürütülmesine yönelik çalışmalar gerçekleştirilmiş ve buna yönelik merkezi satın alma süreci ve prosedürleri oluşturulmuştur.

iç kontrol ve iç denetim süreçlerinin uyumlaştırılması: Satın alım sonrasında, örgütün iç kontrol süreci işleyişinde, birinci seviye kontroller ilgili departmanların mevcut iş süreçleri içerisine yerleştirilmiş, iç kontrol departmanı ise bu kontrolleri ikincil seviyede kontrol edecek şekilde yapılanmıştır. Bununla birlikte, iç denetim biriminin işleyişinde, önceden lokasyon temelli denetim süreci benimsenmiş iken, satın alım sonrasında risk ve süreç temelli denetim yöntemine geçildiği görülmektedir. Ayrıca, yıllık risk değerlendirmesi ve denetim planının oluşturulması, örneklem seçimi, denetim risk seviyelerinin belirlenmesi, bu risk seviyeleri üzerinden denetim bulgularının önem derecelerinin belirlenmesi, rapor yazım ve yayım yöntemleri ve kullanılan sistemlerde de ana gruba uyumlu hale gelinmiştir.

\subsection{Satın Alan Örgüte Kültürel Uyum}

Incelenen vakada, aralarında doğrudan bir kültürel uyum bulunmayan örgütler arasında sınır ötesi bir satın alma işlemi gerçekleşmiştir. Yapılan araştırmalara (Bereskin ve diğ., 2018; Lee ve diğ., 2018; Khan ve diğ., 2020) göre, kültürel uyumsuzluk, birleşme ve satın almaların başarısını çok büyük ölçüde etkilemekte, bu nedenle kısa sürede giderilmesi gerekmektedir. Satın alım sonrasında, ana örgüte kültürel uyumun sağlanabilmesi için bir dizi uyum mekanizması işletilmiştir:

Grup stratejik önceliklerinin ve değerlerinin benimsenmesi: Satın alım sonrasında, satın alan grubun temel stratejik önceliklerinin çeşitli sunumlar ve ortak konferanslar ile duyurulduğu, her bir stratejik önceliğin örgüt üst yönetiminden başlayarak orta kademe yöneticilere ve çalışanlara aktarıldığı gözlenmiştir. Söz konusu stratejik öncelikler, satın alınan kuruluşta gerçekleştirilen projeler ile ilişkilendirilmiş, projelerin çıktılarının her bir önceliğe nasıl katkı sağladığına üst yönetim nezdinde yapılan sunumlarda ve toplantılarda yer verildiği görülmüştür. Stratejik önceliklerin örgütün intranetinde, faaliyet raporlarında, yıllık vizyon toplantılarında da düzenli olarak yer bulduğu, hatta bunlarla ilgili dijital ortamda çeşitli etkinlikler de düzenlendiği görülmektedir. Benzer şekilde, grup değerlerinin de satın alınan örgütte kullanılmaya başlandığı, çeşitli projeler ile ilişkilendirildiği, örgütün faaliyet raporlarında ve kurumsal sunumlarında kullanılmaya başlandığı gözlemlenmiştir.

Karşılıklı ziyaretler ve çalıştayların düzenlenmesi: Satın alım sonrasında, satın alınan örgüte çok sayıda ziyaret gerçekleştirilmiş, bu ziyaretlerin bazıları satın alınan kuruluşun farklı birimlerinin çalışanlarının da dahil edilmesi suretiyle ortak uyum projeleri gerçekleştirilmesi için, bazıları da doğrudan birim müdürleri ve üst yönetim seviyesinde karşılıklı etkileşimin arttırılması ve 
satın alan kuruluşun vizyon ve stratejilerinin satın alınan kuruluşa aktarılması amacı ile gerçekleştirilmiştir. Uyum sürecinin sonlarına doğru satın alınan kuruluştan da satın alan kuruluşa farklı birimlerin çalışanlarından oluşan takımların gerek eğitim gerekse karşıııkı iletişimin arttırıması amacı ile satın alan kuruluş nezdindeki seminer ve çalıştaylara katılma amacı ile ziyaretler gerçekleştirildiği görülmektedir. Bu sayede, iki kuruluşun çalışanları arasındaki iletişimin arttırılması, karşılıklı beklentilerin doğru ifade edilmesi ve daha kısa süre içerisinde aynı vizyon ve stratejilerin benimsenmesine çalışıldığı, bu anlamda kişi-örgüt bütünleşmesinin tetiklenerek kuvvetlendirildiği görülmektedir.

Çalışanlara eğitim ve kariyer olanakları sağlanması, rotasyon ve yönetici transferleri: Kültürel uyumun önemli bir parçası da satın alınan kuruluş çalışanlarına tanınan eğitim ve kariyer olanaklarıdır. Satın alınan örgüt çalışanlarına çeşitli sınıf içi ve web tabanlı eğitimler sağlanmış, ayrıca satın alınan örgütte yabancı dil kursları oluşturulmuştur. Bunun yanında, grubun farklı coğrafyalarda açılan bazı kariyer fırsatlarının, satın alınan örgütte de yayımlanmaya başladığı görülmüştür. Ayrıca, satın alınan örgütün çalışanlarına grup bünyesindeki diğer ülkelerde de görev yapma imkânları tanındığı gözlemlenmiştir. Bununla birlikte, satın alınan kuruluşun bazı üst düzey yöneticilerinin satın alım sonrasında ana kuruluş yapısında farklı coğrafyalarda üst düzey görevlere atandıkları, ana kuruluşun bazı üst düzey yöneticilerinin de satın alınan kuruluşa Yönetim Kurulu üyesi olarak atandıkları gözlemlenmiştir.

Ortak toplantılar ve video konferansların düzenlenmesi: Ortak toplantılar ve video konferanslar da iki kuruluş arasındaki etkileşimin ve kültürel uyumun arttırılması için uygulanan yöntemlerden biridir. Örneğin grup bünyesindeki farklı ülkelerin eşlenik birimleri, düzenli olarak gerçekleştirilen canlı video konferanslarda, gündemdeki iş süreçleri, mevzuat değişiklikleri ve yeni konular hakkında bilgi alıp vermekte, yeni metotlar, çalışma prensipleri ve sonuçlar hakkında fikir alışverişinde bulunmaktadır.

Çalışan memnuniyeti anketlerinde, grup uygulamalarına uyum sağlanması: Satın alım öncesinde de örgüt bünyesinde düzenli olarak çalışan bağlılığı ve memnuniyeti anketleri düzenlenmekteydi. Ancak, satın alım sonrasında, söz konusu uygulamalarda grubun küresel düzenlemelerine ve standartlarına uyumlu olacak şekilde değişiklikler gerçekleştirilmiş, ayrıca çalışan bağlıı̆̆ anket sonuçları, grubun diğer ülkelerde de uyguladığı şekliyle ülke performans puanına da etki etmeye başlamıştır.

Kurum logosu, içsel doküman formatları ve kurumsal imza formatlarının değişmesi: Satın alım sonrasında, örgütün logosu temel bazı özelliklerini koruyacak şekilde değişmiş, içsel raporlar, sunumlar ve diğer dokümanlarda yeni logo ve ana grubun doküman formatları kullanılmaya başlanmış, ayrıca e-postalarda kullanılmakta olan imzaların da formatı ana grup formatlarına uygun olacak şekilde güncellenmiştir. Söz konusu değişimler, örgütün üst yönetimi tarafından çalışanlara öncesinde e-posta, video konferanslar ve web tabanlı kısa videolar ile duyurularak, onları bilgilendirerek gerçekleştirilmiştir.

\subsection{Tartışma}

Birleşme ve satın alma araştırmalarının çoğu ya birleşme öncesi konulara ya da birleşme sonrası bütünleşmeye (Bauer ve Matzler, 2014) odaklanmakta ve esas değerin satın alım veya birleşmeden sonraki dönemde yaratılacağı konusunda uzlaşmaya varmaktadır (Haspeslagh ve Jemison, 1991). Bütünleşme odaklı araştırmalar çoğunlukla bütünleşme yaklaşımları (Weber ve Tarba, 2010), bütünleşme tipolojileri (Angwin ve Meadows, 2015), farklı bütünleşme türleri (Birkinshaw ve diğ., 2000), bütünleşmenin hızı (Bauer ve diğ, 2016), bütünleşme önlemleri (Bauer ve diğ., 2017), sosyokültürel ve insan faktörleri (Stahl ve diğ., 2013; Stahl ve Voigt, 2005) veya satın almalar sırasında iletişim (Angwin ve diğ., 2016; Schweiger ve Denisi, 1991) gibi içsel faktörlere odaklanmaktadır. Bu çalışmada ise, yurtdışı merkezli bir grubun Türkiye Bankacılık sektöründeki bir örgütü satın alması örneğine odaklanılarak, satın alım sonrasında örgütsel uyumun sağlanması yolunda uygulanan mekanizmalar, yapısal, fonksiyonel ve kültürel uyum boyutlarında ele alınarak, uygulanan bütünleşme mekanizmalarının hangilerinin bu üç farklı uyum boyutlarına hizmet ettiği ortaya konulmaktadır. Bunun yanında, satın alınan örgütün farklı birimlerinde uyum sağlanması yönünde atılan adımlarla örgütsel değişimin ne derece yoğun gerçekleştiği - veya gerçekleşmediği - araştırımaktadır. Ayrıca, uyum mekanizmalarının uygulanış biçimlerinin farklılaşıp farklılaşmadığı irdelenmektedir.

Yazında genellikle aynı ülke içinde yapılan birleşme veya satın alma örnekleri üzerinde değerlendirmeler yapılırken (örnek, Bernad ve diğ., 2010, İspanya; Gomes ve diğ., 2012, Nijerya; Ron ve Matte, 2014, Hollanda; Lina ve Graziano, 2015, Litvanya; George ve diğ., 2016, Japonya; Johan, 2018, Endonezya), sınır ötesi birleşme ve satın alma örnekleri (örnek, Goddard ve diğ., 2012; Asya ve Latin Amerika) az sayıda çalışmada incelenmiştir. Bu nedenle, sınır ötesi bir satın alma sürecinin (Avrupa ve Türkiye) incelendiği bu çalışma, ilgili alan için önemli katkılar sunarak literatürdeki mevcut bilgi birikimini zenginleştirmektedir.

Birleşen, satın alınan örgütlerin kurumsal çevreleri, birleşme ve satın alma süreci ve gerçekleşen işlemin başarısı açısından önemlidir. Bu nedenle, Türkiye'den bir örneğin incelenmesi, çoğunlukla gelişmiş ülkelerde yapılan birleşme/satın alma örnekleri (Lee ve diğ., 2018; Mahadewi, 2018, Liu ve diğ., 2019, Zhou ve diğ., 2018; Renneboog ve Vansteenkiste, 2019) üzerinde duran literatür açısından önemlidir.

Araştırmada birincil (görüşme, gözlem) ve ikincil kaynaklardan elde edilen bilgiler, satın alınan örgüt düzeyinde çeşitli değişimlerin yaşandığını göstermektedir. Satın alınan örgütün çevresindeki en önemli değişim paydaşlarla ilgili çevresel 
değişimdir. Satın alımdan sonra, farklı yapı ve süreçlere sahip başka bir örgüt (satın alan) ana paydaş konumuna gelmiş, bunun yanında satın alan örgütün çevresi de satın alınan örgüt için yeni ve belirleyici bir çevre haline gelmiştir. Yeni bir paydaş ve çevre ile karşı karşıya kalmak, yeniden uyum sağlanması gerekliliğini ortaya çıkarmıştır. Uyum sağlama sürecinde, değişime yol açan iki temel unsur olmuştur. i) Satın alan kuruluşun talepleri: Satın alan kuruluş, satın alınan kuruluşun pek çok açıdan kendisine benzer hale gelmesini istemiştir. ii) Çok uluslu bir grubun parçası haline gelmenin getirdiği gereklilikler: Yönetişim, standardizasyon, izleme, raporlama, denetim ve mevzuat yükümlülüklerine uyum sağlama gerekliliği ortaya çıkmıştır.

Kral ve Kralova (2016), örgütsel değişimin en temel göstergesinin örgüt yapısındaki değişim olduğunu belirtmiştir. Mahadewi (2018), başarılı bir birleşme ve satın alma sonrası bütünleşme sürecinin, büyük bir örgütsel değişimi gerçekleştirmeyi sağlayacak olan ve liderliği teşvik eden uygulanabilir bir değişim süreciyle mümkün olduğunu belirtmiştir. Burada incelenen vakada da, satın alım sonrasında satın alınan örgütün yapısı satın alan örgüte uyum sağlama yolunda değişim geçirmiş̧ir. Ancak, bu değişimin yoğunluğu örgütün tüm birimlerinde aynı olmadığı gibi aynı zaman diliminde de gerçekleşmemiştir. "Satın alan kuruluşun öncelik verdiği yapı ve süreçler" daha önce uyum döngüsüne girmiş, diğer alanlar ise değişim sürecine daha sonra dâhil olmuştur. Uyum gerekliliği birkaç boyutta değişim gerektirmiştir. Bunlar temel olarak yapısal uyum, fonksiyonel uyum ve kültürel uyum boyutlarıdır.

Genel satın alma başarısı, yazında da açıklandığı (Haspeslagh ve Jemison, 1991; Birkinshaw ve diğ. 2000) üzere hem görev bütünleşmesi hem de insan kaynakları bütünleşmesi süreçlerinin etkin yönetimine bağlı olmaktadır. Uyum süreci bir bütün olarak ele alındığında, çeşitli görev ve insan kaynakları bütünleşme mekanizmaları ile satın alan örgüte yapısal, fonksiyonel (süreç temelli) ve kültürel anlamda uyumun sağlanması gerçekleştirilmiştir. Ana kuruluşa uyum sağlanan boyutlara Tablo-1'de değinilmiştir.

Tablo 1: Satın Alım Sonrasında Yapısal, Fonksiyonel ve Kültürel Uyum

\begin{tabular}{|c|c|c|}
\hline $\begin{array}{l}\text { Yapısal Uyum } \\
\text { (Görev bütünleşmesi } \\
\text { mekanizmaları ile) }\end{array}$ & $\begin{array}{l}\text { Fonksiyonel (Süreç Temelli) Uyum } \\
\text { (Görev bütünleşmesi mekanizmaları ile) }\end{array}$ & $\begin{array}{l}\text { Kültürel Uyum } \\
\text { (İnsan kaynakları bütünleşme } \\
\text { mekanizmaları ile) }\end{array}$ \\
\hline $\begin{array}{l}\text { Risk yönetimi ve Krediler } \\
\text { yapılanmalarının değiştirilerek } \\
\text { satın alan kuruluşun yapısına } \\
\text { benzer hale getirilmesi }\end{array}$ & $\begin{array}{l}\text { Örgütün politika ve prosedürlerinin } \\
\text { güncellenerek satın alan grup } \\
\text { politikalarına uyumlu hale getirilmesi, } \\
\text { yeni politika ve prosedürlerin } \\
\text { yayımlanması }\end{array}$ & $\begin{array}{l}\text { Ortak değerler ve stratejik öncelikler } \\
\text { oluşturularak yayımlanması ve teşvik } \\
\text { edilmesi }\end{array}$ \\
\hline $\begin{array}{l}\text { Hazine yapılanmasının } \\
\text { güncellenmesi }\end{array}$ & $\begin{array}{l}\text { Grup uygulamalarına uyumlu şekilde } \\
\text { limitler ve metrikler tanımlanması }\end{array}$ & Ortak proje ekipleri kurulması \\
\hline $\begin{array}{l}\text { Yeni birimler kurulması, bazı } \\
\text { birimlerin yapılanmasının } \\
\text { güncellenmesi }\end{array}$ & $\begin{array}{l}\text { Grup süreçlerine uyumlu olacak şekilde } \\
\text { raporlama ve takip süreçleri oluşturulması }\end{array}$ & $\begin{array}{l}\text { Karşılıklı çalışanların ve yöneticilerin } \\
\text { transfer edilmesi }\end{array}$ \\
\hline $\begin{array}{l}\text { Komiteler yapılanmasının } \\
\text { değiştirilmesi }\end{array}$ & Komitelerin işleyiş şeklinin güncellenmesi & $\begin{array}{l}\text { Çalışanlara yurtdışı ziyaretler ve ortak } \\
\text { eğitim programları düzenlenmesi }\end{array}$ \\
\hline $\begin{array}{l}\text { İç denetim yapılanmasının } \\
\text { değiştirilerek satın alan örgüte } \\
\text { uyumlu hale getirilmesi (Lokasyon } \\
\text { temelli modelden risk temelli } \\
\text { modele geçilmesi) }\end{array}$ & $\begin{array}{l}\text { İç denetim yöntemlerinin satın alan } \\
\text { grubun metotlarına uyumlu hale } \\
\text { getirilmesi }\end{array}$ & $\begin{array}{l}\text { Ortak toplantılar ve video konferanslar } \\
\text { ile çalışanlar arasında etkileşimin } \\
\text { arttırılması }\end{array}$ \\
\hline \multirow[t]{2}{*}{$\begin{array}{l}\text { İç kontrol modelinin güncellenerek } \\
\text { grup yapılanmasına uyumlu hale } \\
\text { getirilmesi }\end{array}$} & $\begin{array}{l}\text { Grup şirketlerinin işleyiş ve karar alma } \\
\text { süreçlerinin güncellenerek daha merkezi } \\
\text { bir yönetim şekline geçilmesi }\end{array}$ & $\begin{array}{l}\text { Üst yönetim tarafından çalışanlara } \\
\text { değişim sürecine ilişkin bilgilendirmeler } \\
\text { yapılması }\end{array}$ \\
\hline & $\begin{array}{l}\text { Performans değerlendirme sisteminin } \\
\text { gruba uyumlu hale getirilmesi }\end{array}$ & \\
\hline
\end{tabular}

Tablo 1'den de görüleceği üzere, yapısal uyum temelde belirli birimlerin ana kuruluşa uyumlu olacak şekilde yeniden yapılanmasıyla gerçekleştirilmiş olsa da, örgüt içerisinde çok sayıda birimin satın almadan önceki yapısını da koruduğu görülmektedir. Yapısal değişimin en yoğun yaşandığı birimler krediler, hazine, izleme, takip, raporlama ve denetim birimlerdir. Bu alanda değişimin diğerlerine görece daha sınırlı kaldığı alanlar ise temelde işkolları, satış yapılanması ve teknoloji birimleri olmuştur. Fonksiyonel uyum, ana kuruluşun politika, prosedür ve süreçlerine uyumlu politika ve prosedürler oluşturulması, süreçlerin yeniden tasarlanmasıyla gerçekleştirilmiştir. Yapısal uyum ile örgütün belirli birimleri daha çok etkilenirken, fonksiyonel uyum ile örgütün bütünü üzerinde geçerli olacak kural ve prosedürler, iş süreçleri oluşmakta, dolayısıyla örgütün tamamı üzerinde etkili olmaktadır. 
Yazında (örnek: Sales ve Mirvis, 1984; Shrivastava, 1986; Haspeslagh ve Jemison, 1991), uluslararası ortak çalışan toplantıları, kültürel farkındalık seminerleri, ortak proje takımları, deneyimli uzmanların karşılıklı transferi, personel rotasyonu, ortak personel eğitim programları gibi uygulamaların satın alım sonrası bütünleşme sürecini kolaylaştırdığı belirtilmektedir. Yapılan incelemeye göre, bu mekanizmalardan "ortak toplantılar düzenlenmesi”, "ortak proje ekiplerinin oluşturulması", "çalışanlar arasında bilgi birikiminin paylaşımı" mekanizmalarının bu vakada da uygulandığı doğrulanırken, "personel rotasyonu" ve "deneyimli uzmanların karşılıklı transferinin" sınırlı kaldığı görülmektedir. Gerçekleştirilen görüşmeler ve incelenen ikincil verilerden, bunun nedeninin satın alan kuruluşun faaliyet gösterdiği coğrafyalarda konuşulan dil olduğu anlaşılmaktadır. Birleşme ve satın alma sonrası bütünleşme sürecindeki insancıl/yumuşak (soft) konular, ulusal ve örgütsel kültür farklılıkları, Insan Kaynağı uygulamalarındaki farklııklar, liderlik tarzlarındaki farklııklar ve yemek, dil, sosyal değerler ve yaşam tarzı gibi sosyal farklılıklar olarak ifade edilmektedir (Cartwright ve Cooper, 1995; Nur, 2012; Bari ve diğ., 2016). Kedia ve Reddy (2016), iletişimin sınır ötesi satın almaların başarısı üzerindeki önemine dikkat çekmişlerdir. Bari ve diğ. (2019), etkili ve açık bir iletişim sisteminin, satın alım sonrasında çalışanları firma performansını artırmak için önemli ölçüde motive ettiğini belirtmektedir. Birleşme ve satın alma sonrası dönemde, dil öğrenimi ve kültürel değişim sosyal faaliyetlerinin çalışanların uyumluluğunu artırabileceği, bilgi ve teknoloji paylaşım ve aktarım uygulamalarının hızlanmasını sağlayabileceğini belirtmişlerdir. Dil bariyerinin, satın alınan kuruluş çalışanlarının satın alan grubun farklı coğrafyalarında görev almalarına engel oluşturmakta olduğu, bu nedenle, satın alınan kuruluşun çalışanlarının daha çok İngilizce konuşulan coğrafyalarda (örn. ABD) görevlendirildikleri görülmektedir. Söz konusu bariyerin aşılabilmesi için, satın alınan örgütte yabancı dil eğitimlerinin arttırıldığı, çalışanların yabancı dil öğreniminin teşvik edilmeye başlandığı görülmektedir.

Tablo 2: Yazında Başlıca Yapısal, Fonksiyonel ve Kültürel Uyum Mekanizmaları

\begin{tabular}{|l|l|}
\hline Yapısal ve Fonksiyonel Uyum Odaklı Mekanizmalar & Kültürel Uyum Odaklı Mekanizmalar \\
\hline Ortak toplantılar düzenlenmesi & Ortak örgütsel faaliyetler düzenlenmesi \\
\hline Ortak proje ekipleri oluşturulması & $\begin{array}{l}\text { Çalışma saatleri dışında ortak biçimsel olmayan faaliyetler } \\
\text { gerçekleştirilmesi }\end{array}$ \\
\hline Çalışanlar arasında bilgi birikiminin paylaşılması & Ortak personel eğitim programları düzenlenmesi \\
\hline Deneyimli uzmanların karşııılı transferi & Çalışanlar arasında iletişimin arttırılması \\
\hline Çalışan rotasyonu & Sosyokültürel eğitim \\
\hline Birleşen örgütler arasında kaynak paylaşımı & Expatlardan faydalanılması \\
\hline & $\begin{array}{l}\text { Ortak kimlik ve değerler oluşturularak çalışanlar arasında ortak bir } \\
\text { kültür oluşturulması }\end{array}$ \\
\hline
\end{tabular}

Yararlanılan Kaynaklar: Haspeslagh ve Jemison (1991), Schweiger ve Denisi (1991), Birkinshaw ve diğ. (2000), Vaara ve diğ., (2003), Hebert ve diğ. (2005), Dauber (2009), Bansal (2015)

Kültürel uyumun sağlanmasına yönelik olarak, yazında insan kaynakları bütünleşme mekanizmaları kapsamında işlenen temel unsurlar, iletişim (Schweiger ve Denisi, 1991), iş birliğine yapılan yatırımlar (Schweiger ve Goulet, 2005), expatlardan yararlanılması (Hebert ve diğ., 2005), sosyo-kültürel eğitim (Vaara ve diğ., 2003) ve kimlik oluşturma kampanyalarıdır (Vaara ve diğ., 2007). Bu bağlamda ortak örgütsel faaliyetler düzenlenmesi, çalışma saatleri dışında ortak biçimsel olmayan faaliyetler gerçekleştirilmesi, ortak personel eğitim programları düzenlenmesi mekanizmaları işlenmektedir. Dixon (2005) kültürün "yumuşak" bir husus olduğunu ve örgütlerin olası kültürel çatışmaları ölçebilmek ve yönetebilmek için kültür ile ilgili anketler ve çok sayıda değerlendirme yapmaları gerektiğine dikkati çekmiştir. Kültür ile ilgili hususları yönetebilmek için etkili bir yöntem olarak, herkes için geçerli olacak -örneğin "müşteri odaklı", "yenilikçi”, "sonuç odaklı", "takım odaklı", "saygıı”" bazı kültürel özelliklerin tanımlanması önerilmektedir (Dixon, 2005).

Yazında değinilen yöntemlerin, bu vaka araştırmasında da kendisine yer bulduğu görülmektedir. Bu yöntemlere ilave olarak, grup stratejik hedeflerinin ve değerlerinin satın alınan kuruluşta da benimsenmesini teşvik edici yöntemler (buna yönelik faaliyetler, dijital yarışmalar düzenlenmesi, ödüller verilmesi vb.) uygulanmıştır. Ayrıca, örgütün çalışanlarına grup bünyesinde yurtdışı eğitim ve kariyer fırsatları yaratılması, performans değerlendirme sisteminin satın alan grubun uygulamalarına uyumlu olacak şekilde güncellenmesi gibi mekanizmaların da uygulandığı görülmektedir. Yazında kültürel uyumun sağlanmasına yönelik yöntemlerin çoğunlukla yazılı olmayan kurallar ve yönlendirme mekanizmaları ile gerçekleştirildiği görülmekte iken, incelenen vakada bu yöndeki uyumun daha belirgin ve sayısal ölçümler de içeren performans sistemi, çeşitli metrikler ve limitler gibi mekanizmalar da kullanılarak gerçekleştirildiği görülmektedir. Yazında yer verilen mekanizmalar ve vaka araştırmasında uygulanan mekanizmalara karşılaştırmalı olarak Tablo-3'de yer verilmiştir. 
Tablo 3: Yazında ve Pratikteki Kültürel Uyum Mekanizmaları

\begin{tabular}{|l|l|l|}
\hline \multicolumn{2}{|c|}{ Kültürel Uyum İçin İnsan Kaynakları Bütünleşmesi Mekanizmaları } \\
\hline \# & Yazında & Vakada \\
\hline 1 & Ortak örgütsel faaliyetlerin düzenlenmesi & Çok yoğun olmasa da uygulandığı görülmektedir. \\
\hline 2 & $\begin{array}{l}\text { Çalışma saatleri dışında ortak biçimsel olmayan } \\
\text { faaliyetlerin gerçekleştirilmesi }\end{array}$ & $\begin{array}{l}\text { Satın alan grup yurtdışı merkezli olduğundan yoğunlukla } \\
\text { uygulanmadığı görülmektedir. }\end{array}$ \\
\hline 3 & Ortak personel eğitim programları düzenlenmesi & $\begin{array}{l}\text { Satın alım sonrasında örgütün değişimden etkilenen çoğu birimi } \\
\text { için uygulanmıştır. }\end{array}$ \\
\hline 4 & Çalışanlar arasında etkileşimin arttırıması & $\begin{array}{l}\text { Grup bünyesinde farklı ülkelerden eşlenik fonksiyonların } \\
\text { çalışanlarının belirli konularda karşılıklı bilgi ve deneyimlerini } \\
\text { paylaşabildiği uygulama birliktelikleri kurulmuştur. Ayrıca, iş } \\
\text { ailelerinin kendi içlerinde eşlenikleri ile ortak video konferans } \\
\text { toplantıları düzenlediği görülmektedir. }\end{array}$ \\
\hline 5 & Sosyokültürel eğitim & Sınırlı uygulanmıştır. \\
\hline 6 & Expatlardan yararlanılması & $\begin{array}{l}\text { Satın alınan örgütten gruba doğru üst düzey yönetici } \\
\text { transferleri gerçekleştirildiği görülmektedir. }\end{array}$ \\
\hline 7 & $\begin{array}{l}\text { Ortak kimlik ve değerler oluşturularak çalışanlar } \\
\text { arasında ortak bir kültür oluşturulması }\end{array}$ & $\begin{array}{l}\text { Değerler ve stratejik önceliklerin, grup değerleri ve önceliklerine } \\
\text { paralel hale getirilmesi şeklinde uygulandığı görülmektedir. }\end{array}$ \\
\hline 8 & & $\begin{array}{l}\text { Performans değerlendirme sisteminin gruba uyumlu hale } \\
\text { getirilmesi, güncellenmesi }\end{array}$ \\
\hline 9 & & $\begin{array}{l}\text { Satın alınan örgütün çalışanlarına yurtdışı eğitim ve ziyaret } \\
\text { imkânları sunulması }\end{array}$ \\
\hline
\end{tabular}

Bu çalışmada incelenen birleşme/satın alma örneğinin, "satın alan grup bünyesinde satın alınan bankanın imajı", "grup içindeki diğer ülkelerdeki örgütlerle kıyaslandığında merkezden istenen bilgi, raporlama ve uyum isteklerine hızlı yanıt veriliyor olması" ve "taleplerin hızlı karşılanması" gibi ölçütler dikkate alındığında başarılı olduğu söylenebilir. Bu durum, farklı coğrafyalardaki birleşme ve satın alma örneklerinin daha başarılı olduğu yönündeki yazın bulgularını (örnek, Goddard ve diğ., 2012; Jianbo ve Liu, 2013) desteklemektedir.

Bazı çalışmalarda, özellikle sınır ötesi uygulamalarda, birleşen tarafların kurumsal çevre farklılıklarının birleşme veya satın alma sürecinde ve sonrasında izlenen stratejilerin farklılaşmasına yol açtığı vurgulanmıştır. Örneğin, Hagendorff ve Keasey (2009), Amerika ve Avrupa özelinde bir örneklem üzerinde yaptıkları çalışmada, satın alım sonrasında performansı artırabilmek için Avrupa bankalarının maliyet azaltıcı stratejiler uyguladıkları, ABD bankalarının ise faiz ve faiz dışı gelirleri arttırmaya odaklandıkları sonucuna ulaşmışlardır. Avrupa Birliği tarafından Euro bölgesinde para politikasının etkinliğinin arttırılabilmesi için daha entegre bir bankacılık sektörü oluşturulması yönünde politik baskıların mevcudiyeti (Goddard ve diğ., 2007) bu farklııkları anlamlı kılmaktadır. Bu vaka araştırmasında da, sermayenin etkin kullanımı için grup bünyesinde limitler ve metrikler belirlenerek çok yakından izlenmesi, maliyetlerin etkin yönetilmesine yönelik bütçe çalışmaları yapılması ön plana çıkmakta ve yazın bulgularını desteklemektedir.

Lee ve diğ. (2018), araştırmalarında, firmaların insan kaynaklarının birbirlerine benzerliği ölçüsünde birleşme ve satın almaların daha olası olduğunu ve birleşme / satın alma performansının da arttığını belirtmişlerdir. Bereskin ve diğ., (2018), satın alım sonrası bütünleşme sürecini etkileyen önemli faktörlerden biri olarak örgütler arası kültürel benzerliğe dikkat çekmektedir. Bu vakada satın alan ve alınan örgütler arasında da kültürel benzerlikler bulunmaktadır. Aynı sektörde ve iş alanında faaliyet göstermenin getirdiği kültürel benzeşim, hedeflerle yönetim, performans sistemi, kurumsal yönetim ve etik kültürü, yetki ve delegasyon ayrımları bunun örnekleridir. Söz konusu kültürel benzerliklerin, satın alım sonrasında, satın alan gruba hızlıca uyum sağlanmasında etkili olduğu görülmektedir.

Bunların ötesinde, birleşme ve satın almanın bir sonucu olarak satın alınan örgütte kaçınılmaz olarak bazı değişimler gerçekleştiğinden, "anlaşmanın tasarlandığı ve yürütüldüğü sürecin yönetilmesi", sonucun başarısı üzerinde etkili olan en önemli unsurlar arasına girmektedir (Wright ve diğ., 2001). Pek çok çalışmada, birleşme ve satın alma stratejisinin etkinliğinin, ayrıntılı planlama ve dikkatli uygulamadan geçtiği vurgulanmaktadır (örnek, Salter ve Weinhold, 1979; Blake ve Mouton, 1984; Jemison ve Sitkin, 1986). 


\section{SONUÇ}

Örgütsel değişim, kimi zaman örgütün kendi kararı ile, kimi zaman da çevresindeki dış unsurların etkisi ile başlayabilmektedir. Her iki durumda da aslen değişen çevreye uyum sağlama yönünde atılan adımlar örgütsel değişimi de beraberinde getirmektedir. Birleşme ve satın almalarda da örgütler bir değişim sürecine girmektedir. Bu araştırmada satın alımla birlikte yeni bir grubun üyesi haline gelen örgütte yapısal, fonksiyonel ve kültürel boyutlarda değişim gerçekleşmiştir.

Birleşme ve satın alma sonrasında uyumun sağlanabilmesi için örgütsel değişim de kaçınılmazdır. Ancak, bu değişimin örgütün yapı, işleyiş ve kültürel unsurlarında ne derece gerçekleşeceği de yine örgütün bu unsurlarda ne derece yapılanmış ve kuvvetli olduğuyla ters orantılı olduğu kadar, satın alan kuruluşun da bu unsurları değiştirme isteği ile doğru orantılı olmaktadır. Vakada örgütün satış, pazarlama, bilgi teknolojileri gibi bazı unsurlarının diğerlerine görece çok daha az değişim geçirdiği görülmektedir. Görüşme ve gözlemlerden edinilen bulgular, söz konusu alanlarda örgüte daha az müdahale edildiğini göstermektedir. Bunun bir nedeninin, satın alan kuruluşun, önceki satın alma tecrübelerinden de hareketle satın aldığı örgütlerde bazı fonksiyonları çok yakından takip ederek, bu alanlarda kendi grup yapısına tam uyumlu şekilde faaliyet gösterilmesine yönelik değişiklikler yaparak ilerleme isteği olduğu anlaşılmaktadır. Bununla birlikte, bu alanlarda örgütün halihazırda faaliyet gösterdiği çevrede öncü olması ve başarııı bir performans göstermesi de değişimin bu alanlarda daha sınırlı olması sonucunu doğurmuştur.

Birleşme ve satın alma sonrası bütünleşme sürecinin başarılı bir şekilde gerçekleştirilebilmesi için, görevlerin ve kültürlerin benzer derecede uyumlaştırılması önemli olmaktadır (Bauer ve diğ., 2015). Araştırılan vakada da iki örgütün görev ve kültürlerinin uyumlaştırılabilmesi için hem görev bütünleşmesi hem de kültürel bütünleşme yöntemlerinin birlikte kullanılması, yazındaki önermeleri desteklemektedir. Bunun bir sonucu olarak da, örgüt yapıları ve işleyiş şekilleri birbirine yakınlaşmış, ayrıca insan kaynakları yönetimi uygulamaları da benzer hale gelmiştir.

Satın alım sonrasındaki uyum sürecinde gözlemlenen diğer bir önemli husus da, uyum mekanizmalarının uygulanış biçimlerindeki farklılıktır. Yapısal uyumun sağlanması için uygulanan uyum mekanizmalarının, çoğunlukla yazında da değinilen yöntemler ile gerçekleştirildiği görülmektedir. Bununla birlikte, örgütsel uyumun gerçekleştirilebilmesi için uygulanan insan kaynakları ve görev bütünleşmesi mekanizmalarının uygulanış biçimlerinin, bu vakada yazında aktarıldığı biçiminden bir miktar farklılaştığı görülmektedir. Özellikle fonksiyonel uyum ve kültürel uyumun sağlanması için uygulanan mekanizmaların yazında değinilen uygulanış biçimlerinden farklılaşarak, yazılı kurallar, metrikler ve limitler kullanılmak suretiyle ve yoğun bir izleme faaliyeti gerçekleştirilerek yapıldığı görülmektedir. Bu noktada satın alan grubun yazılı kurallar, politikalar prosedürlerin yoğun şekilde yer bulduğu kendi yapı ve işleyiş biçiminin, satın aldığı örgütü kendisine uyumlaştırma sürecinde uyguladığı mekanizmaları da kullanma biçimini etkilediği sonucuna ulaşılmaktadır. Çok sayıda ülkede faaliyet gösterilmesi nedeniyle grup bünyesindeki örgütlerin daha standart bir şekilde izlenebilmesi ve grup stratejik hedeflerine doğru yönlendirilebilmesi için yönetim biçiminde çeşitli limitler, metrikler, izleme ve raporlama metotları uygulanması, vaka konusu örgütün değişim sürecinde de etkili olmuştur. Bir holding bakış açısıyla farklı coğrafyalardaki faaliyetlerini belirli standartlar ve minimum gereklilikler ile yönetme anlayışı gösteren grubun, Türkiye'deki satın alma faaliyeti sonrasında bünyesine yeni katılan vaka konusu örgütte uyguladığı uyum mekanizmaları da bu yönetim biçimine paralel şekilde evrilmiştir. Bu kapsamda, fonksiyonel ve kültürel uyum için ortak politika ve prosedürler, yazılı kurallar, limitler, eşik değerler ve ortak yöntemler kullanılması suretiyle, örgüt faaliyetleri hakkında bilgi alma, örgütü grup hedefleri doğrultusunda yönlendirme ve takip süreçleri uygulanmıştır. Bunun bir sonucu olarak da, örgütün satış ve pazarlama gibi temel iş alanlarındaki değişim daha sınırlı kalırken, risk yönetimi, izleme, raporlama ve kontrol gibi alanlarında diğer ülkelerdeki satın alma sonrası bütünleşme süreçlerine benzer şekilde ana gruba büyük ölçüde uyumlu bir yapı ve işleyiş biçimi oluşturulmuştur. Sonuç olarak bu vaka araştırmasında, satın alım sonrasında değişime uyum sağlayabilmek yönünde atılan adımlar, insan kaynakları ve görev bütünleşmesi çerçevesinde irdelenmiştir. Yazında değinilen mekanizmaların pratikte daha geniş bir uygulama alanı bulduğu, tanımlanmış mekanizmalara ilave yöntemlerin de kullanılabildiği, ayrıca söz konusu yöntemlerin uygulanış biçimlerinin de satın alan ve satın alınan örgütlerin özelliklerine bağı olarak değişebildiği sonucuna ulaşılmıştır. İnsan kaynakları ve görev bütünleşmesi mekanizmalarının birlikte uygulanmasıyla, yalnızca örgüt yapısı değil, işleyiş süreçleri ve örgüt kültürü de değişim geçirmekte, dolayısıyla örgüt eski normalden bütünüyle bir değişim sürecini yaşayarak yeni normale evrilmektedir.

\section{REFERANSLAR}

Abbasoğlu, O.F., Aysan, A.F., Güneş, A. (2007), Concentration, Competition, Efficiency and Profitability of the Turkish Banking Sector in the Post-Crises Period, MPRA Paper No.5494, [online], http://mpra.ub.uni-muenchen.de/5494/ [Erişim tarihi: 12.02.2020[

Aguilera, R. V., ve Dencker, J. H. (2004). The role of human resource management in cross-border mergers and acquisitions. International Journal of Human Resource Management, 15, 1355-1370.

Akhavein, J. D., Berger, A. N. ve Humphrey, D. B. (1997), The effects of megamergers on efficiency and prices: evidence from a bank profit function, Review of Industrial Organization, 12, 95-139.

Altunbaş, Y. ve Ibanez, D. M. (2004), Mergers and acquisitions and bank performance in Europe. The role of strategic similarities, ECB working paper series no. 398 (European Central Bank, Frankfurt, Germany). 
Angwin, D. ve Meadows, M. (2015). New integration strategies for post-acquisition management. Long Range Planning, 48(4), $235-251$.

Angwin, D. N., Mellahi, K., Gomes, E., ve Peter, E. (2016). How communication approaches impact mergers and acquisitions outcomes. International Journal of Human Resources Management, 27(20), 2370-2397.

Bansal, A. (2015), Understanding the integration mechanisms practiced during organizational change: Evidence from five $M \& A$ transactions, Journal of Organizational Change Management, 28(6), 929-947.

Bari, M.W., Abrar, M., Bashir, M., Baig, S.A. ve Fanchen, M. (2019). Soft Issues During Cross-Border Mergers and Acquisitions and Industry Performance, China-Pakistan Economic Corridor Based View, [online], https://journals.sagepub.com/doi/full/10.1177/2158244019845180, [Erişim tarihi: 03.03.2020]

Bari, M. W., Fanchen, M. ve Baloch, M. A. (2016). Management practices and performance of mergers and acquisitions in Pakistan: Mediating role of psychological contract. SpringerPlus, 5, Article 1527. doi:10.1186/s40064-016-3184-3

Bauer, F. ve Matzler, K. (2014). Antecedents of M\&A Success: The Role of strategic complementarity, cultural fit and degree and speed of integration, Strategic Management Journal, 35, 269-291.

Bauer, F., Hautz, J., ve Matzler, K. (2015). Unveiling the myths of M\&A integration: challenging general management and consulting practice", Journal of Business Strategy, 36(2), 16-24

Bauer, F., King, D. ve Matzler, K. (2016). Speed of acquisition integration: Separating the role of human and task integration, Scandinavian Journal of Management, Elsevier, 32(3), 150-165.

Bauer, F., Dao, M. A., Matzler, K., ve Tarba, S. Y. (2017). How Industry Lifecycle Sets Boundary Conditions for M\&A Integration, Long Range Planning, 50(4), 501-517

Bereskin, F., Byun, S.K., Officer, M.S. ve Oh, J. (2018). The Effect of Cultural Similarity on Mergers and Acquisitions: Evidence from Corporate Social Responsibility, Journal of Financial and Quantitative Analysis, 53(5), 1995-2039.

Bergman, D.R., Savoia, J.R.F. ve Souza, B.M. (2015). Evaluation of Merger and Acquisition Processes in the Brazilian Banking Sector by means of an Event Study, Review of Business Management, 17(56), 1105-1115.

Bernad, C., Fuentelsaz, L. ve Gomez, J. (2010). The effect of mergers and acquisitions on productivity: An empirical application to Spanish banking, Omega-International Journal of Management Science, 38(5), 283-293.

Bernard, H.R. (2011), Research Methods in Anthropology, Qualitative and Quantitative Approaches, Rowman, Altamira.

Bijlsma-Frankema, K. (2001), On managing cultural integration and cultural change processes in mergers and acquisitions, Journal of European Industrial Training, 25(2/3/4), 192-207.

Birkinshaw, J., Bresman, H. ve Hakanson, L. (2000). Managing the post-acquisition integration process: How the human integration and task integration processes interact to foster value creation. Journal of Management Studies, 37, 395-425.

Blake, R.R. ve Mouton, T.S. (1984) Solving costly organizational conflicts: Achieving intergroup trust, cooperation and teamwork. San Francisco: Jossey-Bass.

Bryman, A. (2008), Why do researchers integrate/combine/mesh/blend/mix/merge/fuse quantitative and qualitative research, Advances in Mixed Methods Research, ss. 87-100.

Carleton, R.J. (1997) Cultural Due Diligence, Training, 34, 67-80.

Cartwright, S. ve Cooper, C. L. (1995). Organizational marriage: "Hard" versus "soft" issues? Personnel Review, 24(3), 32-42.

Cartwright, S., Teerikangas, S., Rouzies, A. ve Wilson- Evered, E. (2012). Methods in M\&A - a look at the past and the future to forge a path forward. Scandinavian Journal of Management, 28, 95-106.

Cassia, L. ve Minola, T. (2012), "Hyper-growth of SMEs”, International Journal of Entrepreneurial Behavior \& Research, 18(2), 179-197.

Coşkun, S.A. ve Karğın, S. (2016). Sınır Ötesi Birleşme ve Satın Almaların Bankaların Finansal Performansına Etkileri: Üç Banka Üzerinde CAMELS Analizi, Muhasebe ve Finansman Dergisi, Ocak 2016, 41-60.

Creswell, J.W. (2012). Educational research: planning, conducting, and evaluating quantitative and qualittive research, Pearson.

Dauber, D. (2009), Mergers and acquisitions, integration and culture: what we have learned and failed to learn in the past ten years, Conference of the International Association of Cross-Cultural Competence and Management (IACCM) and CEMS Doctoral Seminar, June 2426, Vienna.

DeLong, G. (2003), Does long-term performance of mergers match market expectations? Evidence from the US banking industry, Financial Management 32, 5-25.

DeYoung, R., Evanoff, D. D. ve Molyneux, P. (2009) Mergers and Acquisitions of Financial Institutions: A Review of the Post 2000 Literature, Journal of Financial Services, 36, 87-110.

DiMaggio, P. J. ve W. Powell. (1983). The iron cage revisited: Institutional isomorphism and collective rationality in organizational fields . American Sociological Review, 48, 147-160. 
Dixon, I. (2005). Cultural issues in mergers and acquisitions: Human resource management. [online] https://www2.deloitte.com/content/dam/Deloitte/us/Documents/mergers-acqisitions/us-ma-consulting-cultural-issues-in-ma-010710.pdf [Erişim tarihi: 11.10.2019]

Eisenhardt, K.M. (1989). Building theories from case study research. Academy of Management Review, 14(4), 532-550.

Eisenhardt, K.M. ve Graebner, M.E. (2007). Theory building from cases: Opportunities and challenges. Academy of Management Journal, 50(1), 25-32.

Elena, B. ve Pascal, F. (2013). The Determinants of Mergers and Acquisitions in Banking, Journal of Financial Services Research, 43(2), 165175.

Ellis, K.M. ve Lamont, B.T. (2004), 'Ideal' acquisition integration approaches in related acquisitions of equals: a test of long-held beliefs, Advances in Mergers \& Acquisitions, 3, 81-102.

Fadzlan, S. ve Shah, M. H. (2014). The impact of forced mergers and acquisitions on banks' total factor productivity: empirical evidence from Malaysia, Journal of the Asia Pacific Economy, 19(1), 151-185.

Flick, U. (2009). An introduction to qualitative research,: Sage Publications, London, UK, ISBN: 1446241319.

Gadiesh, O. ve Ormiston, C. (2002), Six rationales to guide merger success, Strategy and Leadership, 30(4), 38-40.

George, E. H., Matousek, R. ve Tzeremes, N.G. (2016) Pre-evaluating technical efficiency gains from possible mergers and acquisitions: evidence from Japanese regional banks, Review of Quantitative Finance and Accounting, 46, 47-77.

Ghauri, P.N. ve Buckley, P.J. (2003). International mergers and acquisitions: past, present and future. Advances in Mergers and Acquisitions, 2, 207-229.

Goddard, J., Molyneux, P., Wilson, J. O. S. ve Tavakoli, M. (2007) European banking: an overview, Journal of Banking \& Finance 31, 19111935.

Goddard, J. Molyneux, P. ve Zhou, T. (2012) Bank mergers and acquisitions in emerging markets: evidence from Asia and Latin America, European Journal of Finance, 18(5), 419-438.

Gomes ve diğ. (2012) HRM issues and outcomes in African mergers and acquisitions: a study of the Nigerian banking sector, International Journal of Human Resource Management, 23(14), 2874-2900.

Hagendorff, J. ve Keasey, K. (2009). Post-merger strategy and performance: evidence from the US and European banking industries, Accounting and Finance, 49, 725-751.

Hajro, A. (2015). Cultural influences and the mediating role of socio-cultural integration processes on the performance of cross-border mergers and acquisitions, The International Journal of Human Resource Management, 26(2), 192-215.

Haspeslagh, P. ve Jemison, D. (1991). Making Acquisitions Work, Insead and The University of Texas, 1-31.

Hebert, L., Very, P. ve Beamish, P.W. (2005), Expatriation as a bridge over troubled water: A knowledge-based perspective applied to crossborder acquisitions, Organization Studies, 26(10), 1455-1476.

Hitt, M. A., Stewart, J. B. ve Lyman, W.P. (2009), Management, Second Edition, Pearson Prentice Hall, New Jersey.

Houston, J. F., James, C. M. ve Ryngaert, M. D. (2001), Where do merger gains come from? Bank mergers from the perspective of insiders and outsiders, Journal of Financial Economics 60, 285-331.

Ioannis, A. ve Panayiotis, A.P. (2013). Revisiting the merger and acquisition performance of European banks, International Review of Financial Analysis, 29, 237-249.

Isoraite, M. (2009), Importance of strategic alliances in company's activity, Intellectual Economics, 1(5), 39-46.

Jemison, D.B. ve Sitkin, S.B. (1986), Acquisitions-the process can be a problem, Harvard Business Review, 64(2), $107-116$.

Jianbo, S. ve Liu Y. (2013) Cross-border Mergers and Acquisitions of Commercial Banks Based on Strategic Perspective - Case Study of ICBC, Conference: 5th International Conference on Financial Risk and Corporate Finance Management, Jun 29-30, Dalian.

Johan, S. (2018) The Strategic Rational of Banking Acquisition in Emerging Market, Journal of Economics \& Business, 2(1), 13-21.

Johnson, P., Buehring, A., Cassell, C. ve Symon, G. (2007). Defining qualitative management research: an empirical investigation. Qualitative Research in Organizations and Management: An International Journal, 2(1), 23-42.

Kedia, B.L. ve Reddy, R.K., (2016). Language and cross-border acquisitions: An exploratory study. International Business Review, 25(6), 13211332.

Kerber, K. ve Buono, A. F. (2005). Rethinking organizational change: Reframing the challenge of change management. Organizational Development Journal, 23(3), 23-38.

Khan, Z., Soundararajan, V. ve Shoham, A. (2020). Global post-merger agility, transactive memory systems and human resource management practices, Human Resource Management Review, 30, 1-10.

Kral, P. ve Kralova, V. (2016) Approaches to Changing Organizational Structure: The effect of drivers and communication, Journal of Business Research, 69, 5169-5174. 
Lechner, C. ve Dowling, M. (2003), Firm networks: external relationships as sources for the growth and competitiveness of entrepreneurial firms, Entrepreneurship \& Regional Development, 15(1), 1-26.

Lee, K.H., David C. M. ve Xu, E.Q. (2018). Human capital relatedness and mergers and acquisitions, Journal of Financial Economics, 129, 111135.

Lin, B.; Hung, S. ve Li, P. (2006), Mergers and acquisitions as a human resource strategy- Evidence from US banking firms, International Journal of Manpower, 27(2),126-142.

Lina, N. ve Graziano, P. (2015) Assessment of Mergers and Acquisitions in Banking on Small Open Economy as Sustainable Domestic Financial System Development, Economics \& Sociology, 8(1), 71-87.

Lindblom, T. ve Von K.C. (2002) Cross-border bank mergers and acquisitions in the EU, Service Industries Journal, 22(4), 41-72.

Lindner, J. ve Crane, D. (1993), Bank mergers: integration and profitability, Journal of Financial Services Research 7, 35-55.

Liu, H., Li, Y., Yang, R. ve Li, X. (2019): How Do Chinese Firms Perform Before and After Cross-Border Mergers and Acquisitions?, Emerging Markets Finance and Trade, ss.1-17

Mahadewi, L. (2018) Post-merger and Acquisition Integration: A Case Review of Dial Henkel And BP Amoco, International Journal of Business Studies, 2(1), 49-61.

Marks, M.L. ve Mirvis, P.H. (2001), Making mergers and acquisitions work: strategic and psychological preparation, The Academy of Management Executive, 15(2), 80-92.

Masiero, G., Ogasavara, M.H. ve Risso, M.L. (2017), Going global in groups: a relevant market entry strategy?, Review of International Business and Strategy, 27(1), 93-111.

Meglio, O. ve Risberg, A. (2011). The (mis)measurement of M\&A performance - a systematic narrative literature review. Scandinavian Journal of Management, 27, 418-433.

Neuman, W.L. (2003), Social research methods, Qualitative and Quantitative Approaches, Allyn and Bacon, Boston, ISBN: 0205297714

Nicholson, R. ve Salaber, J. (2016). Impact of the Financial Crisis on Cross-Border Mergers and Acquisitions and Concentration in the Global Banking Industry, Thunderbird International Business Review, 58(2), 161-173.

Nur, I.M. (2012). Soft issues around merger and acquisition. Journal Akuntansi \& Management, 7(2), 1-8.

Ortiz-de-Urbina-Criado, M., Guerras-Martín, L.Á. ve Montoro, S.A. (2014), "The choice of growth method: strategies and resources", Academia Revista Latinoamericana De Administracion, 27(1), 30-45.

Pablo, A.L. ve Javidan, M. (2009). Mergers and Acquisitions: Creating Integrative Knowledge, John Wiley \& Sons, New Jersey.

Pfeffer, J. ve Salancik, G. R. (2003). The external control of organizations: A resource dependence perspective: Stanford, CA: Stanford University Press.

Pook, A.S.Y., Chong, C.W. ve Yuen, Y.Y. (2017), Effectiveness of cross-border knowledge transfer in Malaysian MSC status corporations, Review of International Business and Strategy, 27(1), 70-92.

Radova, N. V. (2012). Estimating the Efficiency of Bank Mergers and Acquisitions, Actual Problems of Economics, 136, $203-211$.

Reddy, K.S. (2015) The state of case study approach in mergers and acquisitions literature: A bibliometric analysis, Future Business Journal 1 , $13-34$.

Renneboog, L. ve Vansteenkiste, C. (2019). Failure and Success in Mergers and Acquisitions, Journal of Corporate Finance, 58, 650-699.

Rexhepi, G., Ramadani, V., Rahdari, A. ve Anggadwita, G. (2017), Models and strategies of family businesses internationalization: a conceptual framework and future research directions, Review of International Business and Strategy, 27(2), 248-260.

Ron, M. ve Matte, H. (2014) Merger and Acquisition Activity as Driver of Spatial Clustering: The Spatial Evolution of the Dutch Banking Industry, 1850-1993, Economic Geography, 90(3), 247-266.

Rym, A., Boussemart, J.P., Leleu, H. ve Saidane, D. (2013). Mergers and Acquisitions in European banking higher productivity or better synergy among business lines? Journal of Productivity Analysis, 39(2), 165-175.

Sales, A.L. ve Mirvis, P.H. (1984), When cultures collide: Issues in acquisition, Managing Organizational Transitions, Irwin Homewood, Illionis, ss. 107-133.

Salter, M. S. ve Weinhold, W. A. (1979). Diversification through acquisition. New York: Free Press.

Sarala, R.M., Junni, P., Cooper, C.L. ve Tarba, S.Y. (2014) A Sociocultural Perspective on Knowledge Transfer in Mergers and Acquisitions, Journal of Management, 42(5), 1230-1249.

Sarıgül, H. ve Kurşunel, F. (2012). Bankacılık Sektöründe Birleşme ve Satın Alma Nedenleri: 2001 - 2011 Türkiye Örnekleri, 11.Ulusal İşletmecilik Kongresi , May 2012, Konya.

Schoenberg, R. (2000). The influence of cultural compatibility within cross-border acquisitions: a review. Advances in Mergers and Acquisitions, 1, 43-59. 
Schuler, R. S. ve Jackson, S. E. (2001). HR issues and activities in mergers and acquisitions. European Management Journal, $19,59-75$.

Schweiger, D.M. (2002), M\&A Integration: A Framework for Executives and Managers, McGraw-Hill, New York, NY.

Schweiger, D.M. ve Denisi, A.S. (1991), Communication with employees following a merger: a longitudinal field experiment, Academy of Management Journal, 34 (1), 110-135.

Schweiger, D.M. ve Goulet, P.K. (2005), Facilitating acquisition integration through deep-level cultural learning interventions: a longitudinal field experiment, Organization Studies, 26 (10), 1477-1499.

Shrivastava, P. (1986), Postmerger integration, Journal of Business Strategy, 7(1), 65-76.

Stahl, G. K., ve Voigt, A. (2005). Impact of cultural differences on merger and acquisition performance: A critical research review and an integrative model. Advances in Mergers and Acquisitions, 4, 51-82.

Stahl, G. K., ve Voigt, A. (2008). Do cultural differences matter in mergers and acquisitions? A tentative model for examination. Organization Science, 19, 160-176.

Stahl, G. K., Angwin, D. N., Very, P., Gomes, E., Weber, Y., Tarba, S. Y., Noorderhaven, N., Benyamini, H., Bouckenooghe, D., Chreim, S., Durand, M., Hassett, M. E., Kokk, G., Mendenhall, M. E., Mirc, N., Miska, C., Park, K. M., Reynolds, N.S., Rouzies, A., Sarala, R. M., Soloti, S. L., Jr., Sondergaard, M., ve Yıldız, H. E. (2013). Sociocultural integration in mergers and acquisitions: Unresolved paradoxes and directions for future research. Thunderbird International Business Review, 55, 333-356.

Steele, D.M. (2014), Mergers \& acquisitions: the roles of cultural/relational fit and human integration in cultural/relational convergence and organizational commitment, doctoral dissertation, TUI University, Cypress, California.

Teerikangas, S. ve Very, P. (2006). The culture-performance relationship in M\&A: From yes/no to how. British Journal of Management, 17, 31-48.

Teerikangas, S., Joseph, R.J. ve Faulkner, D. (2012). Mergers and acquisitions: a synthesis. In Faulkner, D., Teerikangas, S. and Joseph, R.J. (eds), The Handbook of Mergers and Acquisitions, 1st edn. Oxford: Oxford University Press, 661-685.

Thakur, M. ve Bansal, A. (2015), A framework of HR enablers for successful M\&A integration, in Risberg, A., King, D.R. and Meglio, O. (Eds), The Routledge Companion to Mergers and Acquisitions, Routledge Publications, Taylor \& Francis Group, London, 40-56.

Tuch, C. ve O'Sullivan, N. (2007). The impact of acquisitions on firm performance: a review of the evidence. International Journal of Management Reviews, 9, 141-170.

Ullrich, J. ve van Dick, R. (2007). The group psychology of mergers \& acquisitions: lessons from the social identity approach. Advances in Mergers and Acquisitions, 6, 1-15.

Vaara, E., Tienari, J. ve Santti, R. (2003), The international match: Metaphors as vehicles of social identity-building in cross-border mergers, Human Relations, 56(4) 419-451.

Vaara, E., Bjorkman, I. ve Stahl, G.K. (2007), Cultural differences and capability transfer in cross-border acquisitions: the mediating roles of capability complementarity, absorptive capacity, and social integration, Journal of International Business Studies, 38(4), 658-672.

Weber, Y. ve Tarba, S.Y. (2010) Human resource practices and performance of mergers and acquisitions in Israel, Human Resource Management Review, 20(3) 203-211.

Willis, J.W. (2007). Foundations of Qualitative Research: Interpretive and Critical Approaches: Sage Publications Inc, Thousand Oaks, US, ISBN: 1412927412

Wright, M., Hoskisson, R.E., Busenitz, L.W. ve Dial, J. (2001), Finance and management buyouts: agency versus entrepreneurship perspectives, Venture Capital: An International Journal of Entrepreneurial Finance, 3(3), 239-261.

Yıldırım, O. (2005) Türk Bankacılık Sektöründe Yeniden Yapılandırma ve Düzenlemelerin Türkiye Ekonomisine Etkileri [online], http://paribus.tr.googlepages.com/o_yildirim5.doc, [Erişim tarihi: 25.12.2018].

Yin, R.K. (2003). Case study research: design and methods (3rd edition). Thousand Oaks, CA: Sage, ISBN: 076192552X

Zhou, A.J., Fey, C. ve Yıldız, H.E. (2018) Fostering integration through HRM practices: An empirical examination of absorptive capacity and knowledge transfer in cross-border M\&As, Journal of World Business, [online], https://doi.org/10.1016/j.jwb.2018.05.005, [Erişim tarihi: 17.01.2021].

Zollo, M., ve Singh, H. (2004), Deliberate learning in corporate acquisitions: post-acquisition strategies and integration capability in US bank mergers, Strategic Management Journal, 25, 1233-1256. 